Article

\title{
Multiple New Paralytic Shellfish Toxin Vectors in Offshore North Sea Benthos, a Deep Secret Exposed
}

\author{
Karl J. Dean ${ }^{1, *}$, Robert G. Hatfield ${ }^{1}$, Vanessa Lee ${ }^{1,2}$, Ryan P. Alexander ${ }^{1}$, Adam M. Lewis ${ }^{1}$, \\ Benjamin H. Maskrey ${ }^{1}$, Mickael Teixeira Alves ${ }^{1}\left[{ }^{1}\right.$, Benjamin Hatton ${ }^{3}$, Lewis N. Coates ${ }^{1}$, \\ Elisa Capuzzo ${ }^{1}$, Jim R. Ellis ${ }^{3}$ and Andrew D. Turner ${ }^{1}$ \\ 1 Centre for Environment Fisheries and Aquaculture Science (Cefas), Barrack Road, Weymouth, \\ Dorset DT4 8UB, UK; Robert.Hatfield@Cefas.co.uk (R.G.H.); Vanessa.Lee@cefas.co.uk (V.L.); \\ Ryan.Alexander@cefas.co.uk (R.P.A.); Adam.Lewis@cefas.co.uk (A.M.L.); Ben.Maskrey@cefas.co.uk (B.H.M.); \\ Mickael.teixeiraalves@cefas.co.uk (M.T.A.); Lewis.Coates@cefas.co.uk (L.N.C.); elisa.capuzzo@cefas.co.uk (E.C.); \\ andrew.turner@cefas.co.uk (A.D.T.) \\ 2 Department of Chemistry, University of Surrey, Guildford, Surrey GU2 7XH, UK \\ 3 Centre for Environment Fisheries and Aquaculture Science (Cefas), Pakefield Road, Lowestoft, \\ Suffolk NR33 0HT, UK; benjamin.hatton@cefas.co.uk (B.H.); Jim.Ellis@cefas.co.uk (J.R.E.) \\ * Correspondence: karl.dean@cefas.co.uk
}

Received: 10 July 2020; Accepted: 25 July 2020; Published: 29 July 2020

check for updates

\begin{abstract}
In early 2018, a large easterly storm hit the East Anglian coast of the UK, colloquially known as the 'Beast from the East', which also resulted in mass strandings of benthic organisms. There were subsequent instances of dogs consuming such organisms, leading to illness and, in some cases, fatalities. Epidemiological investigations identified paralytic shellfish toxins (PSTs) as the cause, with toxins present in a range of species and concentrations exceeding 14,000 $\mu \mathrm{g}$ STX eq./kg in the sunstar Crossaster papposus. This study sought to better elucidate the geographic spread of any toxicity and identify any key organisms of concern. During the summers of 2018 and 2019, various species of benthic invertebrates were collected from demersal trawl surveys conducted across a variety of locations in the North Sea. An analysis of the benthic epifauna using two independent PST testing methods identified a 'hot spot' of toxic organisms in the Southern Bight, with a mean toxicity of $449 \mu \mathrm{g}$ STX eq./kg. PSTs were quantified in sea chervil (Alcyonidium diaphanum), the first known detection in the phylum bryozoan, as well as eleven other new vectors (>50 $\mathrm{\mu g}$ STX eq. $/ \mathrm{kg}$ ), namely the opisthobranch Scaphander lignarius, the starfish Anseropoda placenta, Asterias rubens, Luidia ciliaris, Astropecten irregularis and Stichastrella rosea, the brittlestar Ophiura ophiura, the crustaceans Atelecyclus rotundatus and Munida rugosa, the sea mouse Aphrodita aculeata, and the sea urchin Psammechinus miliaris. The two species that showed consistently high PST concentrations were C. papposus and A. diaphanum. Two toxic profiles were identified, with one dominated by dcSTX (decarbamoylsaxitoxin) associated with the majority of samples across the whole sampling region. The second profile occurred only in North-Eastern England and consisted of mostly STX (Saxitoxin) and GTX2 (gonyautoxin 2). Consequently, this study highlights widespread and variable levels of PSTs in the marine benthos, together with the first evidence for toxicity in a large number of new species. These findings highlight impacts to 'One Health', with the unexpected sources of toxins potentially creating risks to animal, human and environmental health, with further work required to assess the severity and geographical/temporal extent of these impacts.
\end{abstract}

Keywords: paralytic shellfish toxins; benthic organisms; starfish; saxitoxins; sunstar; sea chervil 


\section{Introduction}

Paralytic Shellfish Poisoning (PSP) is the human illness commonly associated with the consumption of seafood that have bioaccumulated Paralytic Shellfish Toxins (PST) primarily in, but not limited to, bivalve molluscs [1,2]. Production of these toxins are associated with the formation of Harmful Algal Blooms (HABs), which are caused by certain specific phytoplankton species in marine environments [3]. Specific species of cyanobacteria have also been implicated in the production of PSTs from freshwater environments [4]. The parent compound saxitoxin (STX), together with many structurally-related analogues [5,6] (Figure 1), are powerful neurotoxins that bind to site 1 of the $\mathrm{Na}^{+}$voltage gated channel [5], blocking synaptic transmission. Symptoms in humans include vomiting, headaches, dizziness, numbness and tingling of extremities, ataxia and paralysis, and in severe intoxications can cause paralysis and death [7]. Consequently, to limit the risk of human consumption of contaminated bivalve molluscs, regulatory testing for the presence of PSTs is a requirement in a number of nations [8], with a maximum permitted level (MPL) of $800 \mu \mathrm{g}$ STX eq/ $\mathrm{kg}$ of flesh, defined in legislation [9], with any bivalve molluscs exhibiting total PST toxicity above this threshold banned from commercial harvest and human consumption.

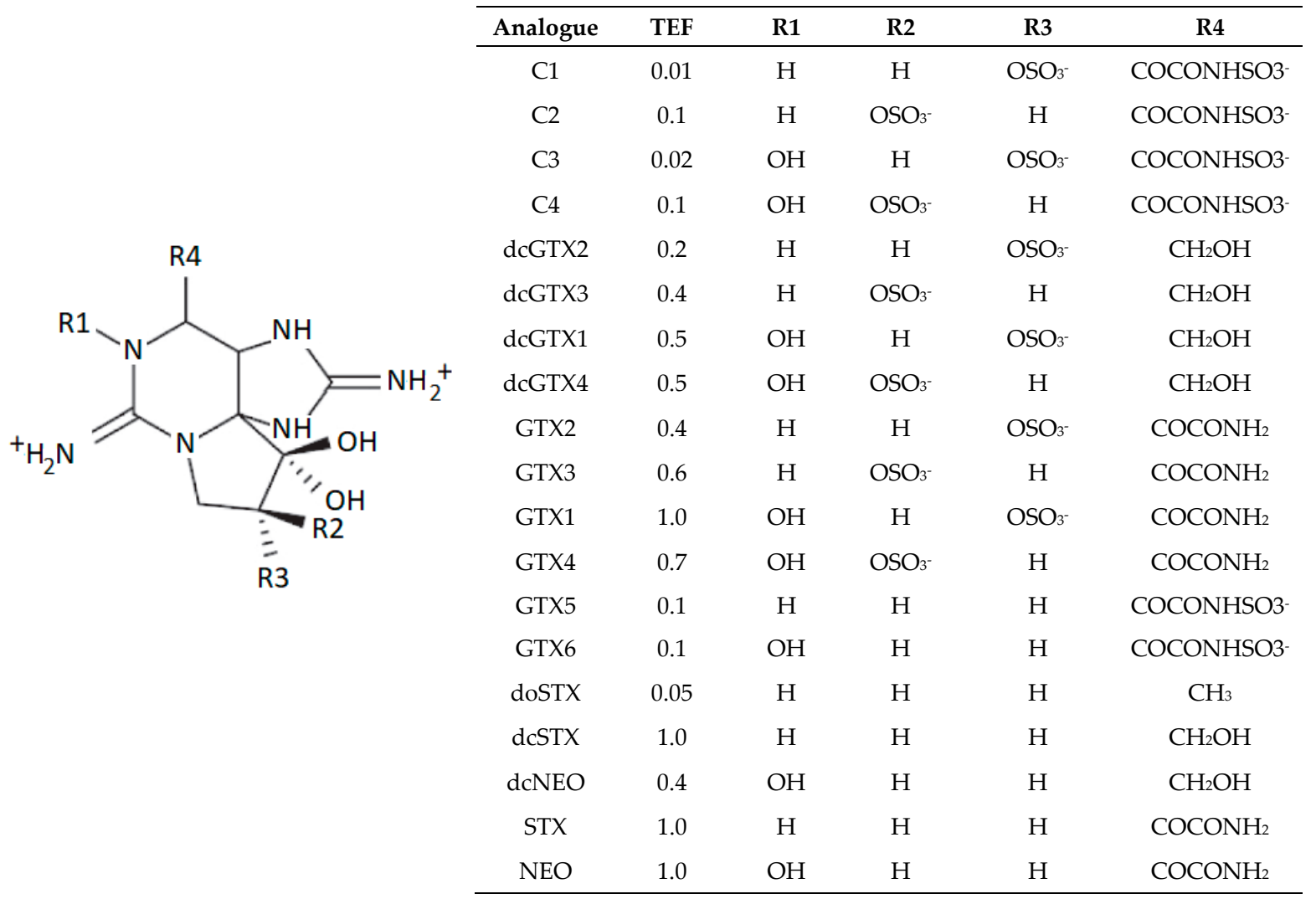

Figure 1. Chemical structures of the commonly-reported Paralytic Shellfish Toxins (TEF = Toxicity Equivalence Factor [10]).

There are a number of cyanobacterial genera known to produce saxitoxins [11-14] of these some proliferate in the planktonic phase and others benthic. Benthic cyanobacterial blooms are typically associated with freshwater and marginal marine habitiats [11,15-17]. Benthic genera such as Lyngbya have both saxitoxin producing species [11,18] and marine examples [15], however, marine species are not currently known to produce saxitoxins and to the authors knowledge, none of the known PST producing 
cyanobacteria are present in freshwater bodies in the UK. Of the dinoflagellate PST producers known globally, the genus Alexandrium is well represented in UK waters [19,20], with the other PST producing species, Pyrodinium bahamense var. compressum and Gymnodinium catenatum being absent. Of the species of Alexandrium present in UK waters, three have been associated with PST production, A. minutum, A. catenella and A. ostenfeldii [21]. Within the UK, both A. catenella [19] and A. minutum [22] have been demonstrated to produce PST at high enough concentrations to cause human health issues in shellfish, whilst local populations of $A$. ostenfeldii have been found to produce only trace levels of PST [19]. The genus Alexandrium is also a well-documented producer of resilient cysts [21]. Cyst deposits can be dense [23], and span wide geographic areas [23-25]. Grazing on cysts has been shown to be a route of toxin accumulation in shellfish [26]. This suggests that benthic organisms, especially those feeding in sediment or filter feeding from the water directly over the sediment, could be exposed to PST if the cysts are ingested during feeding. Consequently, if filter feeders became toxic, in this way, it would create a pathway for PSTs to accumulate in other benthic organisms and benthic feeders, which prey upon these filter feeders.

While, the risk to humans from PSTs is wellunderstood [27], and management systems are in place to limit the risk of intoxications from shellfish consumption, PSTs can also impact animal health with negative effects on a wide range of marine organisms [28], including fish [29-31], whales and seals [32,33], otters [34], sea birds [35,36], sea urchins [37], starfish [38], gastropods [39], as well as bivalve molluscs [40,41]. Furthermore, there have been instances of PSTs affecting terrestrial animals. Notably, after a large winter storm in January 2018 whereby multiple intoxications including two fatalities were reported in dogs walking along East Anglian (UK) beaches, which ingested washed up benthic species that were subsequently found to contain high concentrations of PSTs [42]. Various benthic species were discovered to have accumulated toxins including crabs, flatfish (Limanda limanda) and starfish. The total PST concentration in one sunstar (Crossaster popposus) sample exceeded 14,000 $\mu \mathrm{g}$ STX eq./kg, representing a concentration 18 times higher than the MPL [9]. The presence of PSTs in this environment at this time was unexpected, as toxin outbreaks in classified shellfish harvesting areas typically happen in the south west of England and the west coast of Scotland from March to September [43]. Quantifiable concentrations of PSTs have never been reported in bivalves molluscs from the south east of England, and between 2008 to 2013, no PSTs in shellfish had been detected anywhere across the UK in January [43]. In addition to the unusual spatial and temporal prevalence, the toxin profiles quantified in the stranded organisms were novel. The typical A. catenella [19] (formerly A. tamarense) profile found in Scotland typically consists of a high proportion of the gonyautoxins (GTXs) 1\&4, with lower proportions of neosaxitoxin (NEO), GTX2\&3 and saxitoxin (STX) [43]. A. minutum [20,22] found in SW England consistently produces a GTX2\&3 and STX profile. The profile determined in the samples associated with the dog intoxications, however, was dominated by decarbamoylsaxitosin (dcSTX) with low relative proportions of STX, gonyautoxin 5 (GTX5) and deoxydecarbamoylsaxitoxin (doSTX). Consequently, the profile resembled the decarbaomyl PST dominated profiles that have undergone enzymatic change, commonly seen in some clam species [44,45], suggesting the possible presence of the transformative enzymes carbomylase [46], and/or sulfocarbamolyase [47] or action by certain bacterial species [48]. Furthermore, the invertebrate species that were implicated were also unexpected. Whilst the accumulation of PSTs in marine organisms other than bivalve molluscs is well-documented [2,32,49-54], PSTs presence in starfish is rarely described [53,55-58], with toxicity generally far lower than the $14,000 \mu \mathrm{g} \mathrm{STX} \mathrm{eq./kg}$ described in England. The presence of highly toxic starfish in the UK benthos in the winter, in a geographic location where PSTs are rarely, if ever, seen in shellfish, with a toxin profile unlike any currently known domestic algal PST producer, required further investigation to help disseminate which/ if any other organisms are implicated and the geographical range of the toxic benthos.

With a potential novel source of high concentrations of PSTs from the benthos around the East coast of the UK, consideration should also be given to the potential impacts on animal and environmental health, 
in addition to the potential for human intoxications that may result from the trophic transfer to edible species of these harmful toxins. Consequently, the presence of these toxins in the benthic epifauna in eastern England represents a real threat to 'One Health' which needs to be explored.

Overall, there is a clear requirement to understand and document the presence of PSTs in the offshore benthos, to investigate any spatial and temporal differences, determine the species most commonly linked to toxin presence and ultimately determine the level of risk to 'One Health' in the UK marine environment.

\section{Results}

\subsection{PST Toxicity}

PSTs were detected and quantified in samples of benthic marine organisms collected in both 2018 and 2019, although total PST toxicity varied greatly, depending on location, year and species. Table A1 in the Appendix A summarises the total PST toxicity data quantified using two independent detection methods for all samples processed. In total, 168 samples consisting of more than 30 identified species were tested (65 samples from 2018 and 103 samples from 2019), with toxins detected above the limit of detection (LOD) in $61 \%$ of all samples (Table 1). The mean toxicity of all samples tested across both years was $127 \mu \mathrm{g}$ STX eq./kg. Results ranged from non-detects to 2,091 $\mu \mathrm{g}$ STX eq. $/ \mathrm{kg}$ quantified in a bryozoan sampled from Station 3 (Dutch waters) in 2019 (Figure 2). PSTs were also quantified in starfish, sunstars, crabs, sea mouse, gastropods, anemones, urchins, bivalve molluscs and shrimp.

\subsection{Method Comparison}

Wherever possible, both liquid chromatography with tandem mass spectrometry (LC-MS/MS) and liquid chromatography with fluorescence detection (LC-FLD) methods were used to detect and quantify PSTs in each sample, to provide extra confidence in any results produced, given that neither method is formally validated for non-bivalve shellfish species. Quantified concentrations, using both methods, were compared for all samples. No significant difference was determined between total PST concentrations at the $95 \%$ confidence level, with a positive correlation for the linear regression $\left(r^{2}=0.87\right)$ evidencing a good agreement between the two methods, with the means tested (calculated as the mean LC-FLD/LC-MS/MS ratio in samples $>80 \mu \mathrm{g}$ STX eq. $/ \mathrm{kg}$ ) difference between the methods showing a $15 \%$ positive bias towards the LC-MS/MS method (Table 2). It is also noted that the LC-MS/MS method is also capable of detecting Tetrodotoxin (TTX) and other TTX analogues, as opposed to the LC-FLD. In this study, TTX was not detected in any of the benthic samples from either year. 
Table 1. Summary of groups, associated species and mean total toxicities ( $\mu \mathrm{g}$ STX eq./kg) and total toxicity ranges ( $\mu \mathrm{g}$ STX eq./kg) for all benthic organisms sampled.

\begin{tabular}{|c|c|c|c|c|c|c|c|}
\hline Faunal Group & Species & Feeding Guild & Mean Toxicity & s.d & Toxicity Range & Number of Samples & \% Samples > LOD \\
\hline Sunstar & Crossaster papposus & SP & 448 & 472 & 98-1275 & 7 & $100 \%$ \\
\hline $\begin{array}{l}\text { Starfish \& Brittlestar (excluding } \\
\text { C. papposus) }\end{array}$ & $\begin{array}{l}\text { Anseropoda placenta, Asterias rubens, Astropecten } \\
\text { irregularis, Henricia oculata, Henricia sp., Hippasteria } \\
\text { phrygiana, Luidia ciliaris, Porania pulvillus, Stichastrella } \\
\text { rosea, Ophiura ophiura }\end{array}$ & SP & 80 & 126 & nd-488 & 50 & $56 \%$ \\
\hline Sea urchins & Echinus esculentus, Echinus sp., Psammechinus miliaris & OG & 75 & 122 & nd-257 & 11 & $36 \%$ \\
\hline $\begin{array}{l}\text { Crustaceans (Natantia } \\
\text { and Stomatopoda) }\end{array}$ & $\begin{array}{l}\text { Rissoides desmarseti } \\
\text { Crangon sp., Pandalus sp., unidentified Natantia } \\
\text { Atelecyclus rotundatus, Atelecyclus sp., Carcinus maenas, } \\
\text { Corystes cassivelaunus, Inachus sp., Liocarcinus depurator, }\end{array}$ & $\begin{array}{c}\mathrm{SP} \\
\mathrm{DS} / \mathrm{SP}\end{array}$ & 161 & 247 & nd-446 & 6 & $50 \%$ \\
\hline $\begin{array}{l}\text { Crustaceans (Anomura } \\
\text { and Brachyura) }\end{array}$ & $\begin{array}{l}\text { Liocarcinus holsatus, Liocarcinus sp., Munida rugosa, } \\
\text { Necora puber, Pagurus bernhardus, Pagurus sp., } \\
\text { Portunidae (indet.) } \\
\text { Goneplax rhomboides }\end{array}$ & SP & 25 & 22 & nd-88 & 37 & $70 \%$ \\
\hline Polychaetes & $\begin{array}{l}\text { Aphrodita aculeata } \\
\text { Aequipecten opercularis, Bivalvia (indet.) } \\
\text { Crepidula fornicata }\end{array}$ & $\begin{array}{l}\text { SP } \\
\text { FF/OG }\end{array}$ & 182 & 175 & nd-386 & 13 & $54 \%$ \\
\hline Molluscs & $\begin{array}{l}\text { Hinia reticulata, Scaphander lignarius } \\
\text { Buccinidae (indet.), Buccinum undatum, Colus gracilus } \\
\text { Neptunea antiqua eggmass }\end{array}$ & $\begin{array}{l}\text { DS } \\
\text { DS/SP } \\
\text { N/A }\end{array}$ & 66 & 51 & nd-172 & 17 & $65 \%$ \\
\hline Actiniaria & $\begin{array}{l}\text { Metridium senile } \\
\text { Anemone (indet.) }\end{array}$ & $\begin{array}{l}\mathrm{FF} \\
\mathrm{P}\end{array}$ & 40 & 44 & nd-150 & 11 & $82 \%$ \\
\hline Sessile colonial fauna & $\begin{array}{l}\text { Alcyonidium diaphanum, Alcyonium digitatum, Haliclona } \\
\text { oculata, Porifera (indet.) }\end{array}$ & FF & 488 & 818 & nd-2090 & 14 & $57 \%$ \\
\hline Other & Parastichopus tremulus, Echiura (indet.) & DF & nd & & nd & 2 & $0 \%$ \\
\hline Total & & & 127 & 301 & nd-2090 & 168 & $61 \%$ \\
\hline
\end{tabular}

nd: not detected. Feeding guilds for benthic invertebrates were assumed to be comprised of one of the following seven categories: filter- and suspension feeders (FF), algal grazers (AG, not sampled in present study), omnivorous grazers (OG), deposit feeders (DF), detritivores/scavengers (DS), scavengers/predators (SP) and facultative predators (P). Feeding guilds adapted from $[59,60]$. 


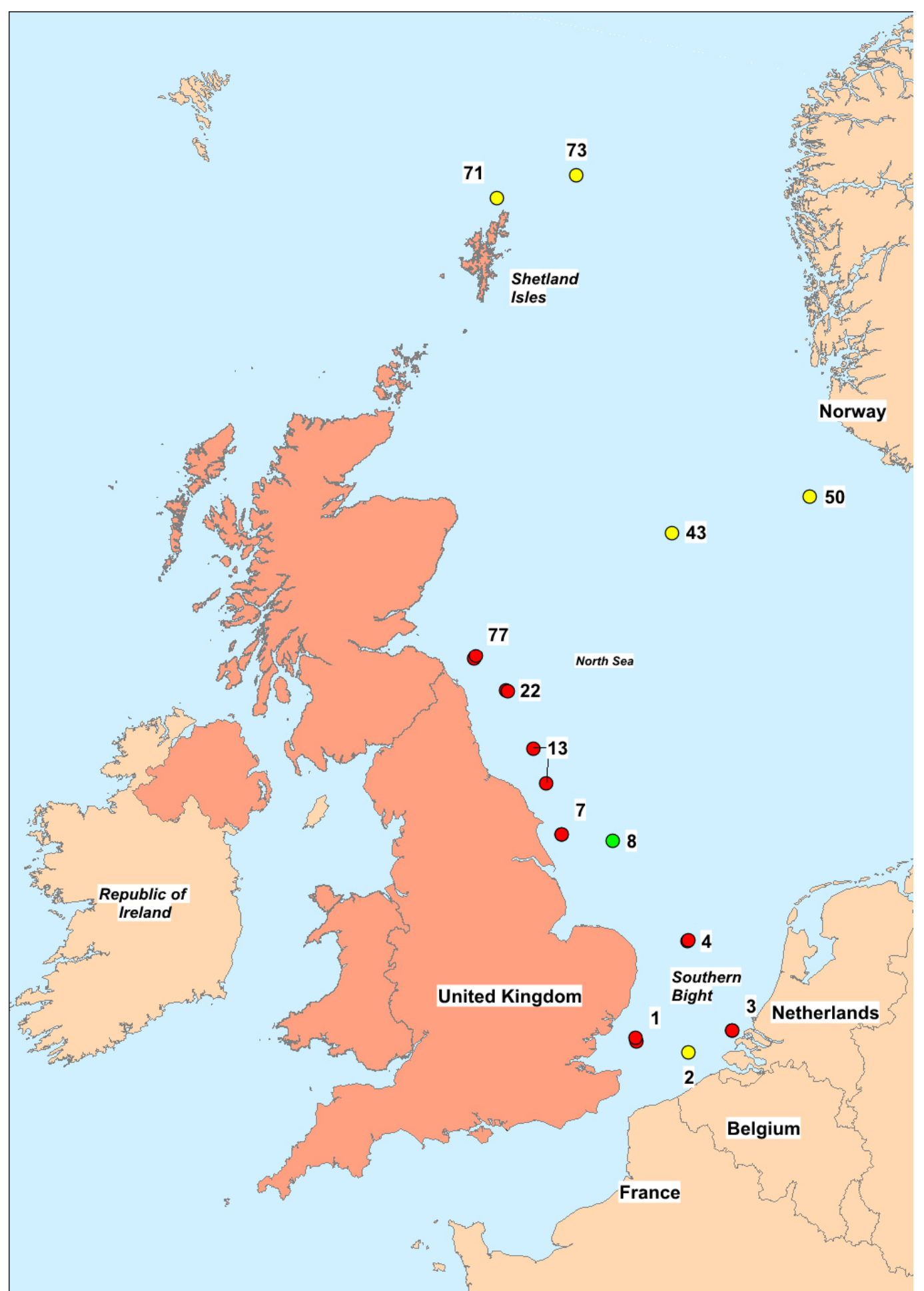

Figure 2. Map indicating locations of each of the sampling locations. Green dots represent sampling locations used in 2018 only, yellow dots represent locations used in 2019 only, and red dots represent locations used in both years. Numbers represent specific the fixed station numbers of the sites. Additional station data can be found in the Appendix A. 
Table 2. Comparison of results between samples analysed by the LC-FLD and LC-MS/MS methods.

\begin{tabular}{|c|c|c|}
\hline Criteria & LC-FLD & LC-MS/MS \\
\hline Mean toxicity ( $\mu$ g STX eq. $/ \mathrm{kg}$ ) & 130 & 145 \\
\hline $\mathrm{Sd}$ & 366 & 334 \\
\hline Maximum toxicity ( $\mu \mathrm{g}$ STX eq./kg) & 2744 & 2091 \\
\hline Correlation & \multicolumn{2}{|c|}{0.87} \\
\hline t score & \multicolumn{2}{|c|}{-0.47} \\
\hline $\mathrm{t}$ crit & \multicolumn{2}{|c|}{2} \\
\hline Means tested & \multicolumn{2}{|c|}{$15 \%$} \\
\hline
\end{tabular}

\subsection{Toxin Profiles}

K-means clustering as detailed in [61,62] was applied to the LC-MS/MS-derived data for all samples with a total toxicity $>80 \mu \mathrm{g}$ STX eq./kg $(\mathrm{n}=35)$ (Figure 3), with the analysis identifying three distinct toxin profiles based on STX equivalents. Cluster one was associated with a high proportion $(78 \%$ of total toxin content) of dcSTX with lower relative concentrations of GTX5 (4\%), STX (17\%) and trace levels of other toxins (1\%). This profile was associated with samples obtained from sites in the Southern Bight (Stations 1-3) and sites in the more western parts of the North Sea (Stations 71, 73 and 77) and was the most common profile ( $49 \%$ of all samples $>80 \mu \mathrm{g}$ STX eq. $/ \mathrm{kg}$ ). The second cluster was dominated by STX (57\% of toxicity) with smaller proportions associated with GTX2 (17\%), dcSTX (11\%), NEO (5\%), GTX3 (4\%) and other toxins (6\%). Only two sampling locations (7 and 13) exhibited this profile, which was associated with $42 \%$ of the samples $>80 \mu \mathrm{g}$ STX eq. $/ \mathrm{kg}$. All positive samples from both these sites and both years showed this profile. The remaining $8 \%$ of samples $(n=3)$ centred around the third cluster which contained dcNEO $(84 \%)$, with a smaller NEO $(11 \%)$ constituent. These samples were all sourced from Station 1 in 2018.

\subsection{Inter-Group Variability}

Due to the random nature of the species sampling, over 30 different identified species were collected and analysed, with some species collected only once. Consequently, the samples consisting of different species were catalogued into similar taxonomic groups and assessed together to make broad comparisons (Table 1 and Figure 4). The assessment of total toxin concentrations for each group highlighted large variability, with sunstars (C. papposus) and sessile fauna showing the highest toxicities. All sunstars analysed across both years contained PSTs regardless of location, from the East coast of England (Station 7) to the Scottish coast (Station 73). Toxicities ranged from 98 to $1275 \mu \mathrm{g}$ STX eq./kg with a mean of $448 \mu \mathrm{g}$ STX eq./kg $(\mathrm{n}=7))$. One sessile fauna sample from Station 3 in 2019 was found to contain the highest toxicity $(2090 \mu \mathrm{g}$ STX eq. $/ \mathrm{kg})$ out of all samples analysed. Trace toxin concentrations were found in all other taxonomic groups, with the lowest mean toxicity determined in crustaceans (Anomura and Brachyura) (25 $\mu \mathrm{g}$ STX eq. $/ \mathrm{kg}$ ) and the lowest occurrence in sea urchins (36\%). 


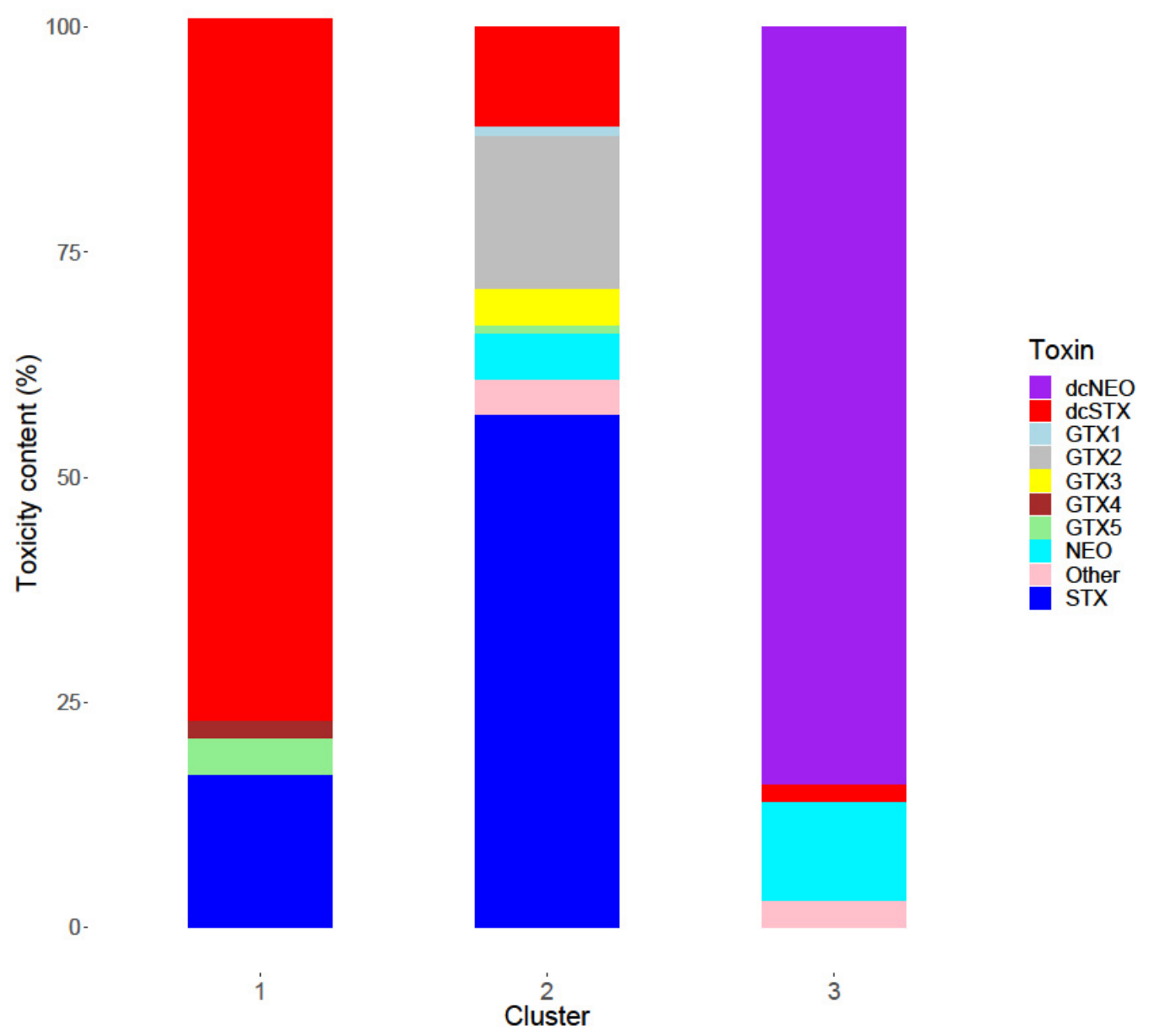

Figure 3. Mean toxin profiles using K-means clustering for all samples with a toxin content $>80 \mu \mathrm{g}$ STX eq. $/ \mathrm{kg}$. Toxic content described as the percentage of total toxicity in $\mu \mathrm{g}$ STX eq. $/ \mathrm{kg}$.

\subsection{Spatial and Temporal Variability}

Toxins were detected in benthic fauna in samples taken during both years at multiple locations. Temporal variability was observed between 2018 and 2019 both overall (Figure 5), on a species level (Figure 4) and spatially (Figure 6). Overall, the total PST levels appeared to increase from 2018 to 2019, with maximum summed concentrations of 446, and $2090 \mu \mathrm{g}$ STX eq./kg respectively, with 2019 having an increased mean, median and range. On a group level the largest temporal variation (Figure 4) was between sessile fauna toxicity from 2018 to 2019, with low concentrations in 2018, but much higher toxicity in 2019, though this is possibly skewed, due to the increased sampling of the apparently more toxic species in 2019. Starfish and brittlestars, crustaceans (Anomura and Brachyura), molluscs and sea anemones (Actiniaria) all showed low concentrations of PST in both 2018 and 2019. Only one sunstar was sampled in 2018 making judgements on their temporal variability difficult, although it still showed toxicity (227 $\mu \mathrm{g}$ STX eq. $/ \mathrm{kg}$ ). Although, the overall toxin concentrations seemed to increase from 2018 to 2019, PSTs at Station 1 appeared to decrease, with all nine samples analysed in 2018 PST-positive with an average toxicity of $131 \mu \mathrm{g}$ STX eq. $/ \mathrm{kg}$, whereas in 2019 only $25 \%$ of samples contained detectable levels of toxins with an average toxicity of $15 \mu \mathrm{g}$ STX eq./kg. Spatial variability was notable (Figures 6 and 7) with a 'hot spot' located at Station 2 in the Southern Bight of the North Sea. The mean toxicity at this sampling site was $429 \pm 438 \mu \mathrm{g}$ STX eq. $/ \mathrm{kg}(\mathrm{n}=8)$, which was more than double the toxicity of all other stations tested across 
both years, showing a total PST range of 88-1461 $\mu$ g STX eq./kg. All samples analysed from Station 2 contained PSTs, regardless of species. Although, this location was only sampled in 2019. Station 3 saw the highest toxicity in a sample of Alyoniudium diaphanium, statistically (Figure 6), this was an outlier with the highest other toxic sample at that station being a common shore crab (Carcinus maenas) sampled in 2018 and found to contain just $44 \mu \mathrm{g}$ STX eq./kg. Station 7 showed a high range of toxicities in 2019, however the median was low, showing that most samples contained little or no detectable levels of toxins, with the results skewed by one highly toxic sunstar sample. Figure 7 summarises all starfish and brittlestar toxicity data from each station. Starfish and brittlestar toxin data were analysed separately as these species were sampled extensively $(n=50)$ from all stations, giving a far more robust data set. From these data, notably higher toxicities were evident in samples taken from Stations 1 and 2, in comparison to all other locations, giving good evidence that toxicity is potentially dependent in part on geographical location.

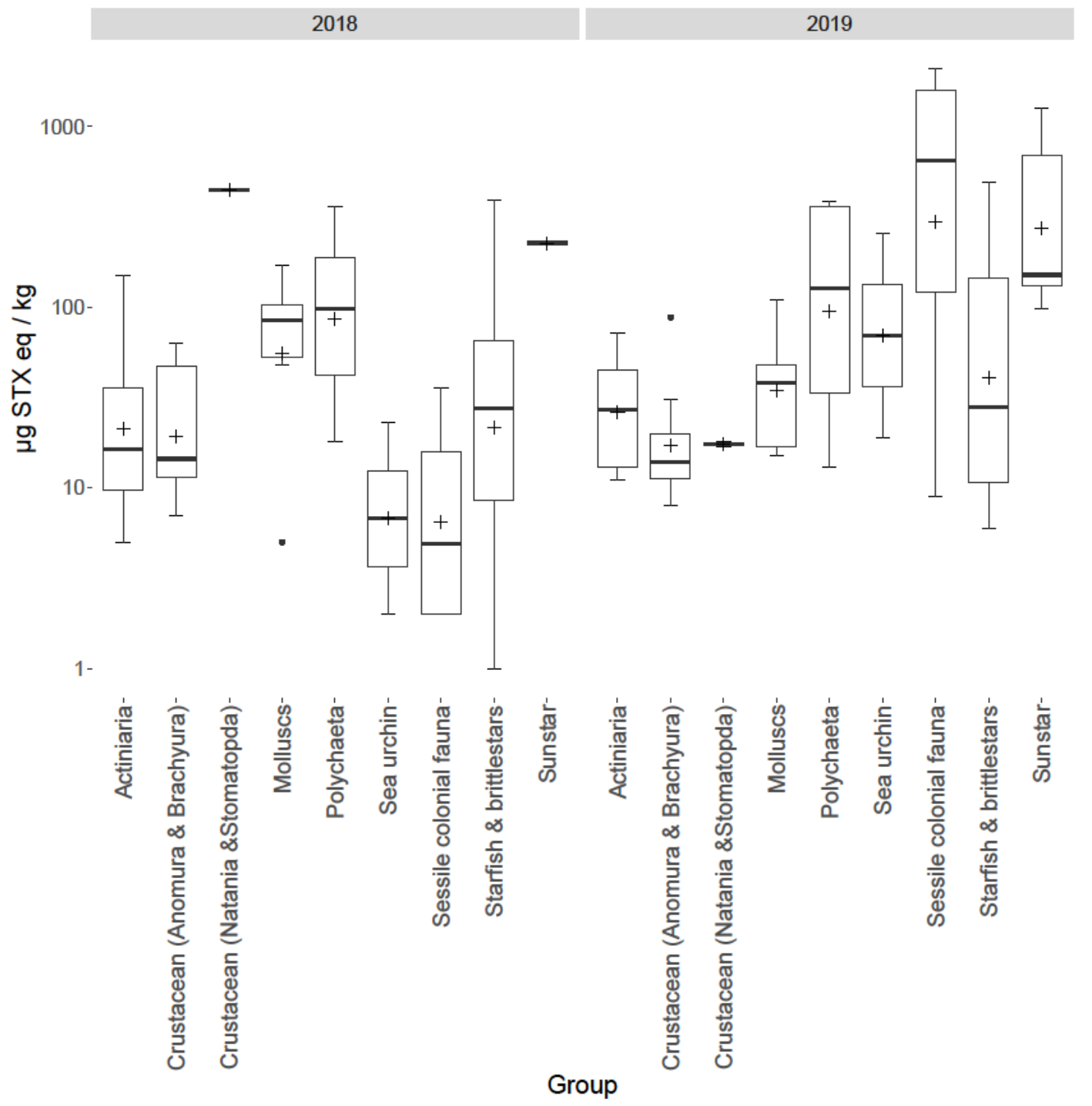

Figure 4. Box and whisker plot highlighting group means (cross), 1st and 3rd quartiles, outliers (dots). and inter quartile ranges for all groups sampled from 2018 and 2019. 


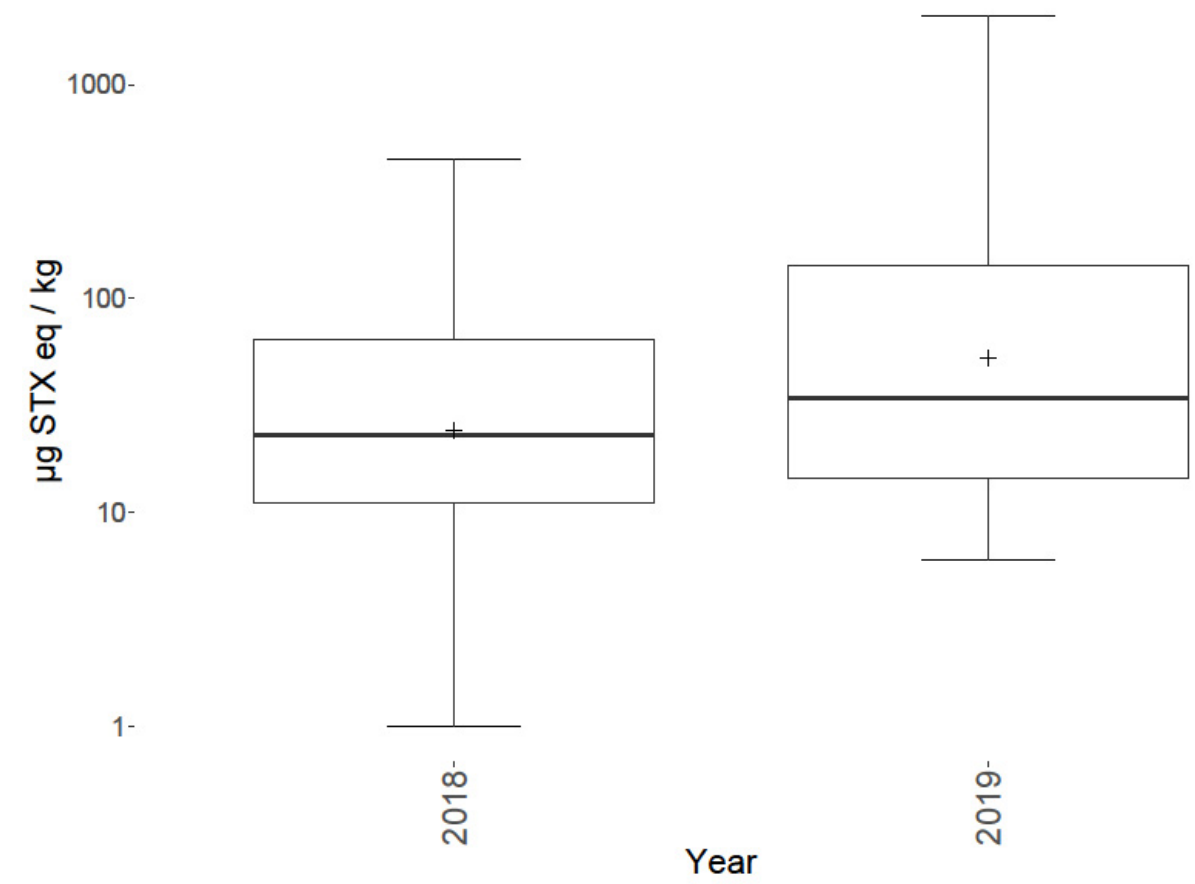

Figure 5. Box and whisker plot highlighting group means (cross), 1st and 3rd quartiles, outliers (dots) and inter quartile ranges for total toxicity for all samples, separated into each year.

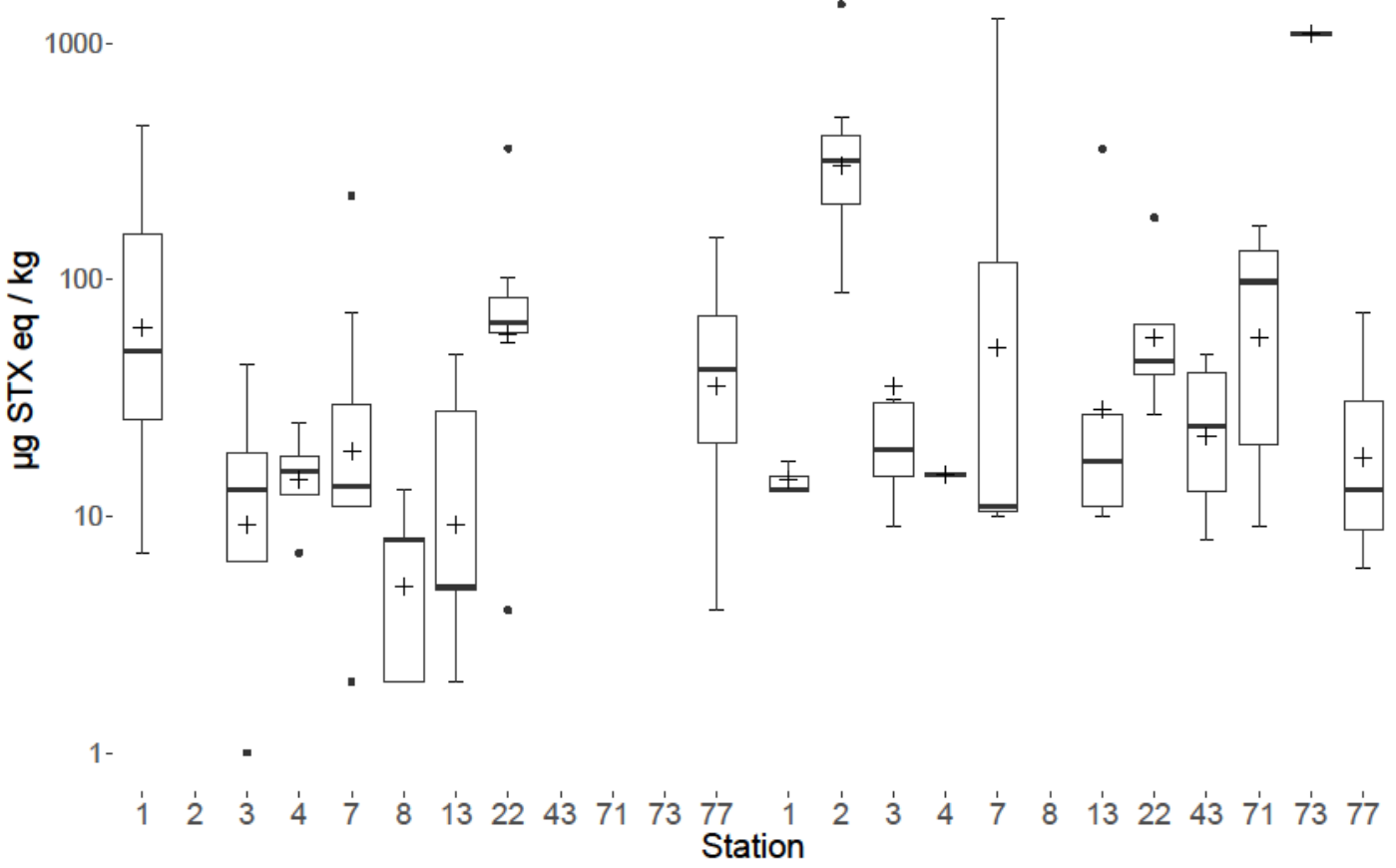

Figure 6. Box and whisker plot highlighting station means (cross), 1st and 3rd quartiles, outliers (dots) and inter quartile ranges for all samples at all stations for 2018 and 2019 separately. 


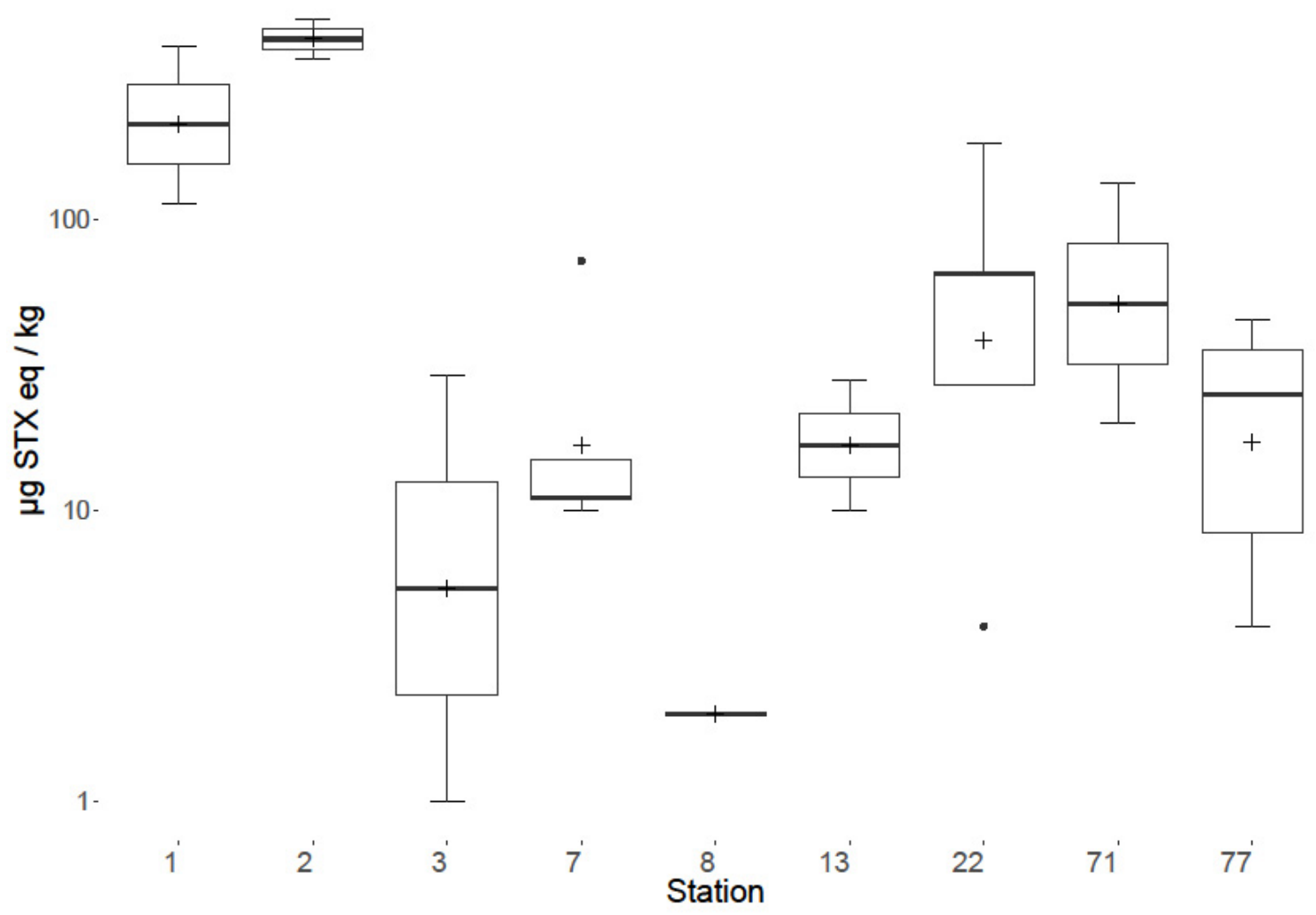

Figure 7. Box and whisker plot highlighting group means (cross), 1st and 3rd quartiles, outliers (dots) and inter quartile ranges of all samples within the Starfish and brittlestars group (excluding sunstars) from all stations for 2018 and 2019 combined.

\subsection{Statistical Analysis}

An ANOVA was performed on all variables, which highlighted group $(p=0.012)$, station $(0.00006)$, year $(p=0.03)$ and bottom salinity $(p=0.03)$ as having a statistical effect on toxicity at the $95 \%$ confidence level. The year having a statistical effect on toxicity could be confounded by the sampling of more potentially toxic species during 2019. There was no statistical effect of depth $(p=0.60)$, bottom temperature $(p=0.06)$, surface temperature $(p=0.92)$ or surface salinity $(p=0.69)$ on toxicity. A Principal Component Analysis (PCA) confirmed these results, in that group and location were positively associated with toxicity. However, there was no association found between the environmental variables. A linear mixed effect model was fitted with group as a fixed variable and station as a random variable, which highlighted sunstar toxicity as statistically different from other groups $(p=0.0021)$. A second linear mixed effect model was fitted with group as a random variable and station as a fixed variable. This analysis highlighted Station 2 toxicity as statistically different from other stations $(p=0.0009$; with Station 8 also showing significantly lower toxicity against the remaining stations, $p=0.003$ ). A Tukey's multiple comparison of means test results confirmed the linear model's hypothesis for both group and station analysis. These results add weight to the original analysis that indicated Station 2 to be a potential 'hot spot' of toxicity, and that sunstars showed a significantly higher level of toxicity to other groups. 


\section{Discussion}

\subsection{Occurrence of Toxins}

The vast majority of PST occurrence data generated globally relates to the presence of toxins in bivalve mollusc shellfish harvested from designated shellfish harvesting areas within inshore marine waters, as monitored under regulatory surveillance programmes $[7,63]$. Consequently, toxin prevalence data has, to date, typically focussed on a restricted range of taxa, the majority of which are bivalve molluscs, with occasional reference to marine gastropods [52,64] and crustaceans [65-68]. While, the occurrence of PST in other marine invertebrates is less well-understood, there has been an increasing number of reports of PSTs in echinoderms, gastropods and barnacles [2,53,58,69]. Even less frequently, with the exception of offshore scallop harvests [70], findings of toxins have been reported in more offshore benthic samples. Consequently, there is little information regarding the potential uptake, presence, or depuration of toxins from offshore, non-bivalve invertebrate fauna. The data generated in this study demonstrate, for the first time, extensive PST accumulation in the marine benthos across a large range of taxonomic groups across a geographical range from the Southern Bight to the Shetland Islands.

Four of the samples analysed (two colonies of A. diaphanum and two specimens of $C$. papposus) contained total summed PSTs above the EU MPL, highlighting some benthic species are capable of accumulating PSTs to dangerous levels if consumed by mammals. Notable toxicity above $200 \mu \mathrm{g} \mathrm{STX} \mathrm{eq./kg}$ was also discovered in sea mouse, shrimp, common starfish, green sea urchin and brittlestar. Consequently, to the authors best knowledge, this is the first detection of PSTs in the phylum bryozoan (A. diaphanum), as well as eleven other new vectors ( $>50 \mu \mathrm{g}$ STX eq. $/ \mathrm{kg}$ ), specifically the gastropod Scaphander lignarius, the starfish Anseropoda placenta, Asterias rubens, Astropecten irregularis, Luidia ciliaris and Stichastrella rosea, the brittlestar Ophiura ophiura, the crustaceans Atelecyclus rotundatus and Munida rugosa, the sea mouse Aphrodita aculeata, and the sea urchin Psammechinus miliaris.

While, there is evidence for the presence of PSTs in the benthos, the primary source is still unknown. The global literature has mostly been able to link toxicity in marine invertebrates to the presence of blooms of known PST producers and subsequent trophic transfer. In this case, there is no evidence of a causative algal bloom at the time of sampling, across any of the sampling regions in either year. In this study, toxin content was geographically widespread, and ANOVA and PCA analysis confirmed a lack of correlation between toxicity and oceanographic factors, such as depth, temperature and salinity. Many organisms are known to graze on benthic cyanobacterial mats and so this could represent a source for toxins in organisms encountering these cyanobacterial proliferations if they were toxic. While, intertidal areas in the North Sea are known to experience cyanobacterial growth [16], there is little evidence to suggest that they proliferate at depth in temperate, deep, marine waters. In this study, as the majority of samples originated from deeper waters and not from coastal or transitional waters, there is no evidence to support benthic cyanobacterial mats as a source of saxitoxins in the contaminations presented, herein. However, it represents a potential source especially in fringing marine waters. Two other plausible causes of PST accumulation in the benthos, include the bioaccumulation of toxins from sedimentary algal cysts and/or the presence of PST producing bacteria, possibly in symbiosis with one or multiple benthic organisms. Alexandrium cyst populations can be present for hundreds of miles alongshore [24,71] and the toxicity in cysts can be comparable or more than their vegetative counterparts [72]. The presence of an 'algal cyst bed' would mean that the marine benthic fauna is potentially exposed to a highly toxic source, which could accumulate through a wide range of taxa, explaining the presence in all groups tested. There is evidence that once Alexandrium cysts reach the sea floor, the anaerobic and low light conditions can prevent germination indefinitely [73]. The cysts remain viable for many years may explain the presence of PSTs in offshore organisms, whilst inshore shellfish beds along the eastern English coast, 
have exhibited no evidence of toxicity in recent years [43]. Historically the south east of Scotland and north east of England have experienced PST outbreaks, with toxicity detected in shellfish regularly from 1968 to 1990 [65,74]. Later, sporadic Alexandrium algal cyst deposits from Aberdeen to Bridlington were discovered, with toxicity found in shellfish and crabs [75,76]. Since 2015, routine monitoring of phytoplankton detected seven sporadic occurrences of Alexandrium sp. along the east coast of the UK. Five of these were in 2018 (data available from [77]). It should be noted that these sampling points are nearshore, long distances from the offshore sampling locations used in this study. It is possible that these events, both historically and in 2018, could have seeded the benthos around that region with Alexandrium cysts. There is, however, no known domestic algal PST producer that exhibits a dcSTX profile and any cyst bed would have to stretch for hundreds of miles. Bacterial production of PSTs has been described previously [78] with microbiological symbiosis attributed with the accumulation of the neurotoxin TTX in marine life, specifically pufferfish [79] and the starfish Astropecten polyacanthus [80]. A symbiotic bacterial source could explain widespread toxicity if the causative bacteria are present in more than one organism and in multiple geographic locations. Additionally, it could explain why some organisms appear to accumulate more PSTs than others and why toxicity appears across many taxonomic groups. To elucidate the source of PSTs, extensive cyst bed analysis and microbiological screening of live organisms will be required.

\subsection{Method Comparison}

As the aim of this study was to examine the presence of a potentially novel toxin source with an unusual toxin profile in various un-validated matrices, it was important to utilise more than one detection method, in order to provide a higher level of certainty to any results generated. The results generated by LC-FLD and LC-MS/MS on the study samples showed the two methods performed similarly. The LC-MS/MS, however, produced a 15\% positive bias vs the LC-FLD method, in terms of total PST concentrations, which was perhaps unexpected given the lack of chromatographic separation for epimeric pairs by LC-FLD, requiring the assumption that each pair exclusively contains the most toxic epimer, leading to over estimation [81,82]. This is a contributing factor in the samples from Stations 7 and 13 where GTX2 and 3 were present. Additionally, the differences are also likely due to the inclusion of a greater number of toxin analogues, specifically doSTX and dcGTX1, in the LC-MS/MS method and were present in 14 and eight samples respectively. Overall, the two methods compared well, providing confidence in the quantitated concentrations of PSTs reported in a large range of marine benthic organisms. Both the LC-FLD and LC-MS/MS methods have subsequently been validated for gastropods and crustaceans, with results reported elsewhere [83].

\subsection{Toxin Profiles}

Two dominant toxin profiles were identified following the cluster analysis of the quantitative data, one centred around dcSTX and the other containing high proportions of STX. The two profiles appear to be associated with specific locations, with the dcSTX dominant profile associated with samples in the south (Stations 1-3) and north of the study area (Stations 71, 73, 77), with the STX profile present in organisms harvested in more central regions (Stations 7 and 13). This suggests that the toxin profile in the benthos is linked to geographic location, rather than being related to the species of the contaminated organism. The high dcSTX profile is unusual, potentially resulting from enzymatic biotransformation, more specifically the potential action of carbomylase [46] and/or sulfocarbamolyase [47], across the sampled regions other than Stations 7 and 13. Enzymatic hydrolysis of PSTs into decarbamoyl variants has previously been reported in shellfish $[44,46,47,84-86]$. It is described as a species-specific transformation, only in a small number of clam species, so it is unlikely that such transformation is occurring in every species across multiple taxonomic groups, over wide geographic fetches, unless driven by bacteria $[48,78,87,88]$ or other 
unknown means, which are only present in specific locations under certain conditions. In addition to enzymatic decarbamoylation, selective toxin retention or elimination, reductive conversion and hydrolysis are also known to affect toxin profiles in shellfish tissues [89-91]. Selective retention/elimination is highly unlikely here, given the extremely low relative proportions of dcSTX present in toxin-producing Alexandrium species found in the UK. Consequently, without the presence of enzymatic biotransformation, there is the potential for decarbamoylation to be triggered by other mechanisms relating to the conditions within the benthos at the bottom of the North Sea at depths of $30 \mathrm{~m}-170 \mathrm{~m}$. Previous work has also highlighted varying toxin profiles in marine invertebrates in different geographical locations [54,58]. Silva et al. 2018 [58] focussed on three geographical locations with each group of samples showing high proportions of the decarbomyl toxins dcGTX2\&3, whilst Silva et al. 2013 [54] described high dcSTX content in some gastropods and bivalves, which could evidence enzymatic change in those environments. In both studies, profiles varied greatly between species, whereas conversely results reported here show consistent profiles based on location, regardless of taxonomic group. Alternatively, the toxin profiles measured in the benthos here may be similar to the toxin profiles within the primary producers, as seen in some shellfish $[89,92]$. To date, no phytoplankton species, detected in UK waters, have been found to produce any significant levels of decarbamoyl PST analogues. In the absence of both a dcSTX-producing Alexandrium sp. and toxin transformation pathways within the benthos tissues, a potentially novel source of PSTs may be considered. Samples from Stations 7 and 13 contained high proportions of STX profile and GTX2, and the profile was more representative of the profile reported in bivalve molluscs along English and Scottish coasts [43]. Both these stations were close to the extensive coastal cyst beds discovered from 1995 and 1997 [75,76], suggesting Alexandrium cysts as the potential source in these locations. These results could therefore indicate the possibility of two different toxin sources in the benthos, one unknown producing a dcSTX profile and a conventional domestic algal cyst bed producing the STX and GTX 2 profile. Without extensive and widespread sediment analysis, it is impossible to definitively state the source of the PSTs or the reason for the differences in toxin profile.

\subsection{Group Variability}

The data presented here highlights large variability in PST concentrations determined between different benthic groups. Due to the non-targeted nature of the sampling, drawing conclusions on inter-group toxicity is difficult, given that geographic location is also an important factor influencing toxicity, as exemplified by the highly toxic samples from Stations 2-3 and the absence of detectable PST at Station 71 (a linear mixed effect model highlighted Station 2 as having significantly different toxicity from all other stations). Without identifying the primary source of PSTs, and identifying transfer mechanics through the benthos, it is currently impossible to determine the cause(s) of inter-group variability. From these data, however, a variety of organisms in the benthos have accumulated PSTs, highlighting widespread exposure to a PST producer, most notably sunstars and A. diaphanum appearing capable of accumulating high toxin concentrations.

Of the sessile fauna tested, only the bryozoan A. diaphanum contained PSTs above detectable levels. It exhibited the highest toxicity of any sample tested $(2091 \mu \mathrm{g}$ STX eq. $/ \mathrm{kg})$, two of which were above the EU MPL. They exhibited a mean toxicity of $926 \mu \mathrm{g}$ STX eq./kg $(\mathrm{n}=4$, all from 2019), which is higher than sunstar. Bryozoans are filter feeders and responsible for producing a wide range of chemical metabolites [93]. Alcyonidium diaphanum produces a sulfoxonium ion which causes the dermatitis condition 'Dogger Bank Itch' [94]. Due to the high toxicities discovered and its relative abundance in British waters [95], it is plausible that $A$. diaphanum plays an important role in the occurrence and transfer of PSTs in the benthos. As $A$. diaphanum are filter feeders, it is possible that PST accumulation in these organisms are the result of algal cyst ingestion, and that subsequent accumulation in higher trophic organisms is due to predation on 
A. diaphanum. However, A. diaphanum only had high levels of PSTs in the more toxic locations (Stations 2-3), with low toxicities at Station 71, highlighting a similar location-driven toxicity as found for other species, thus potentially ruling it out as the route of PSTs into the benthos. As only four samples were analysed from three locations, all in 2019, the data set is too small to make any conclusions on its spatial and temporal variability, however, their ability to accumulate PSTs is clear.

Sunstar toxicity determined here was lower than the levels of toxicity reported in samples associated with the canine intoxications [42]. However, all sunstars analysed were ubiquitously toxic regardless of location or year. In 2019, the sunstar from Station 7 was toxic (1275 $\mu$ g STX eq./kg), whereas all other organisms tested from Station 7 had no PSTs detected or showed only trace concentrations. Consequently, this provides some evidence for sunstar toxicity being independent from location, which is different to all other groups tested. The results from the linear mixed model support this hypothesis, which highlighted sunstars as having significantly different toxicity to the other groups analysed.

The mechanisms for sunstar toxin presence have yet to be elucidated, with further work involving live organisms required to generate supportive data. The organisms could feasibly accumulate PSTs from a dietary source, which has been used to explain echinoderm toxicity before $[38,53]$. In those cases, starfish toxicity was linked to starfish predation on a highly toxic bivalve food source. Given that scallops are commonly found in deeper offshore waters and are capable of accumulating PSTs [70], this could be a route of trophic transfer into sunstars. In this study, there was no evidence to confirm such trophic transfer, given limited bivalve mollusc samples. However, the accumulation of toxins from a dietary source is unlikely as the most toxic organisms analysed were from a range of feeding guilds (Table 1), with high concentrations observed in both scavenging-predators (C. papposus) and filter-feeders (A. diaphanum). More intensive sampling of benthic invertebrates at specified locations would be required to better understand how toxin concentrations may be influenced by feeding guild and other factors, such as the relationship to the sediment, which may influence interactions with algal cysts or toxic organisms. Additionally, sunstars are unlikely to have vastly different diets to some other starfish species (e.g., Asterias rubens), highlighting starfish and sunstars utilising the same niche showed significantly different toxicities. Sunstars have also been shown to be adaptive hunters, preying on readily available organisms [96], thus, making it unlikely that their prey are the same in all the geographic locations. Although, toxin accumulation in sunstars could feasibly occur following ingestion of algal cysts, it is unclear why any potential accumulation via this route is far more consistent in sunstars than other benthic organisms. Sunstars could have a low toxin depuration rate, as noted in abalone gastropods [97-99], and which could explain consistently high toxicity, potentially making them more at risk than other benthic organisms for accumulating PSTs. This would imply that larger and thus older sunstars [96] should have higher toxicity. The study showed no correlation between diameter of sunstar and toxicity $(n=6)$ (data not shown). For cysts to be the source, sunstars would need to have an active storage mechanism and any cyst deposits would have to be geographically extensive and composed of cysts from different algal species or strains to give rise to the different PST profiles observed within this study. The potential for primary production of PSTs by sunstars is possible, due to a microbial symbiosis similar to that of TTX presence in pufferfish [79]. The presence of TTX producing vibrios has previously been noted in the starfish Astropecten polyacanthus [80]. A symbiotic bacterial source of PSTs could explain the consistent and widespread toxicity in sunstars, which had a statistically different toxicity to all other groups analysed. Ultimately, sunstars acting solely as a primary producer remains unproven noting that sunstars from this study also exhibited the same location driven profile variation as all other groups. Future work, involving sunstars from a range of geographical locations, is required in order to begin to understand the presence and potential accumulation and depuration of PSTs in starfish. Without an extensive uptake, depuration and elimination study, and a full molecular analysis of any associated bacterial fauna, drawing conclusions on whether sunstar toxicity is acquired or produced is currently impossible. 


\subsection{Spatial and Temporal Variability}

Results appear to highlight geographic location as an important factor in toxicity, with high toxicities above $400 \mu \mathrm{g}$ STX eq./kg at Stations 1-3, 7. The highest toxicities in non-sunstars were from Stations 1-3, all located in the Southern Bight. Trace or non-detectable toxicities were found in Stations 4, 8 and 43, which were all further offshore, although ANOVA, PCA and mixed model analysis showed no statistical link between distance from shore and toxicity. Station 73 seemed to exhibit high toxicity, however, only one sample (a sunstar) was analysed, which skewed the analysis. The identification of a potential 'hot spot' at Station 2 was important, showing higher mean toxicities than other stations and statistical differences compared to other locations, noting no sunstars were sampled from this station. Figure 7 illustrates the spatial variability between stations, as the data set is far more robust, given starfish and brittlestars were widely sampled and analysed from most stations. The results showed the highest toxicities in samples from Station 2, with notable toxicity in Station 1 and trace toxicities everywhere else. The location of this hotspot is unexpected given previous reports of a cyst bed and historical PSP events around the region close to Stations 7 and 13. Data from this study shows that samples from these sites are generally low in toxicity, albeit with high variability. Although, toxicity was widespread along the East coast of the UK, both sunstars [100] and A. diaphanum [95] are common in the Bristol Channel and Irish Sea, possibly indicating those areas could also be at risk of exhibiting PSTs in the benthos.

In terms of temporal variability, total toxin concentrations appeared to be higher in samples taken from 2019 in comparison to those sampled during 2018 (Figure 5). However, higher mean toxicities could be a result of more consistently toxic species being sampled, for example, the higher number of sunstars and A. diaphanum sampled in 2019, or by the sampling at a more toxic location, such as Station 2 which was only sampled in 2019. Further analysis in future years is required to determine whether Station 2 remains a region associated with highly toxic benthic organisms over time. Samples taken from Station 1 showed a notable decrease in toxicity from 2018 to 2019, with all 2018 samples showing detectable levels of toxins, with a maximum of $446 \mu \mathrm{g}$ STX eq./ $/ \mathrm{kg}$, as opposed to samples from 2019 where $75 \%$ of samples had no PSTs detected with a maximum of only $17 \mu \mathrm{g}$ STX eq./kg. This represents a large difference between years and indicates that the source that was present in 2018 had either moved or reduced significantly. Given the notable changes in toxin content between the two years, there may be potential differences from current-related movement of benthos and/or cyst beds from site to site over time [101,102]. However, more work is required over a larger number of years and in a higher number of geographical regions to enable any such assessments to be made.

\subsection{One Health Considerations}

Results from this study provide strong evidence for the accumulation of PST in a large range of benthic species over a wide geographical area within the North Sea. Four samples were found to contain total toxin concentrations exceeding the EU MPL of $800 \mu \mathrm{g}$ STX eq. $/ \mathrm{kg}$. The implications of these findings in relation to the risks to consumers of seafood originating from the North Sea is unclear. The most notable human food stuff analysed were shrimps with the highest toxicity determined in shrimp of $445 \mu \mathrm{g}$ STX eq $/ \mathrm{kg}$ from Station 1 in 2018. This evidences toxicity in shrimps following toxin accumulation, as previously reported in samples of penaeid shrimp from Brunei and Malaysia (reviewed in [2]), inferring at least some level of human intoxication risk from ingestion of shrimp caught from certain areas. While, crabs are also a commonly consumed food source, all the crabs analysed in this study were small, mostly non-edible species, with the exception of Necora puber. Numerous reports exist for PST presence in a range of crab samples such as Cancer sp., Fabia sp., Hemigrapsus sp., Pugettia sp., Portunus sp., Pilumnus sp., Metograpsus sp. and Telmessus sp. [2]. Most notably, extreme levels of toxicity have been reported in some species of xanthid crabs where PSP has been measured at concentrations far above the MPL [103]. Trophic transfer of PSTs into 
commercially-important species, specifically edible crab (Cancer pagurus) and lobster (Homarus gammarus) is a potential unregulated intoxication route to humans, as both these species are extensively fished within the inshore waters along the eastern and southern coasts of the UK [104]. Edible crabs in particular are potentially co-inhabiting the benthic environment with the toxic benthos, and are known scavengers that also feed on a wide range of prey [105-108]. Trophic transfer of PSTs into crab species is possible [50,109] and capable of accumulating to levels above the regulatory limit [69], posing the risk that edible crabs species in northern European seas are potentially under risk of accumulating PSTs.

Monitoring PSTs in marine benthos has several drawbacks versus bivalves, primarily that many invertebrates are motile, there are no validated detection methods for most non-bivalve species and uptake and depuration kinetics are un-characterised [69]. As no edible crabs were sampled during the study, the risks are still unclear. Future work is essential to assess the risk in edible crabs and other commercially important, but unregulated vectors.

There is also potential risk to the health of other marine organisms, with high concentrations of toxins accumulating in several benthic species. Benthic toxicity at levels above the EU MPL may have detrimental effects to other species. With some species, such as xanthid crabs and sunstars, known to accumulate high concentrations, trophic transfer and subsequent bioaccumulation could impact upon animal health of higher level predators, such as lobsters and larger crabs [110]. There are reports of some crab species producing the protein saxiphilin which has been postulated as explaining STX-resistance to toxic effects and hence the ability to tolerate toxicity within their flesh [111]. With some organisms known to retain toxicity for long periods of time, risks may be present for a period of many years [112,113].

The presence of toxins in benthic invertebrates that may be washed ashore has societal implications, with beach scavenged crabs and starfish implicated in recent canine deaths [42]. Anecdotally A. diaphanum was found among the stomach contents of a dog that had died following a beach walk in 2005 (pers.comm [114]) and implicated in multiple dog deaths in 2006 [115], however, in neither case were PSTs tested for and no archived samples were stored for retrospective analysis. Consequently, further studies on the spatial, temporal and taxonomic patterns in toxins in benthic invertebrates, especially those that are known to be washed ashore after periods of disturbance, could usefully be undertaken. Also important is determining likely levels of risk to the wider animal and ecosystem health, and therefore 'One Health' within the benthic marine environment when exposed to high levels of PST.

\section{Conclusions}

Analysis of a wide range of benthic marine organisms, sampled over a two-year period from multiple sites within the North Sea, revealed the unexpected presence of PSTs in offshore, benthic environments. PST accumulation was geographically extensive, capable of accumulating to dangerous levels in certain species and was associated with two separate toxin profiles, potentially inferring either more than one toxin source and/or extensive toxin transformation. During the study, 12 new vectors of PSTs were identified, with the sunstar C. papposus and the bryozoan A. diaphanum emerging as key species. Sunstars appeared to always possess PSTs and showed statistically higher toxicity than other taxonomic groups, possibly highlighting that they either produce PSTs or can accumulate and store them. Three sampling stations from the Southern Bight showed high toxin concentrations in sampled species, with data showing a statistical difference from samples taken from other parts of the coast. Currently the 'One Health' risks remain unclear. While, some of the edible organisms were found to be toxic, the likelihood of accumulation in commercially important stocks would need to be assessed. Similarly, the potential threat to animal and ecosystem health needs further investigation. The toxin source of PSTs is also currently unclear, which outlines key areas of future work required. This includes further analysis of benthic organisms from other at risk locations, a higher spatial resolution of toxicity in the Southern Bight and eastern English 
Channel, sediment analysis of the East coast of the UK, uptake, toxin conversion and elimination studies of PSTs in sunstars, and analysis of their microbiological fauna. Ultimately, this work will be able to aid risk managers to better understand the risk to commercially important, but currently unregulated, foodstuffs, as well as any potential risks to animal and ecosystem health.

\section{Materials and Methods}

\subsection{Sample Collection Methods}

Samples were collected during the English International Bottom Trawl Survey (IBTS-Q3) conducted during August 2018 and 2019. These surveys targeted specific locations around the North Sea where a GOV (Grand Overture Verticale) otter trawl net was deployed, configured to IBTS-Q3 series standard, including $20 \mathrm{~mm}$ cod-end liner. Fishing was conducted for $30 \mathrm{~min}$ at a speed of 4 knots. Examples of benthos caught were retained and frozen onboard the vessel from multiple fixed stations (Figure 4), identified before the surveys. Once the surveys were completed, the frozen samples were transported to Cefas where they were held in frozen storage until required for analysis.

\subsection{Samples}

Across the two years, twelve sampling locations were assessed, ranging from the Southern Bight to the north of the Shetland islands (Figure 4). Station locations 1, 3, 4, 7, 13, 22 and 77 were sampled in both years, whereas Station 8 was only sampled in 2018 and Stations 2, 43, 50, 71 and 73 were only sampled during 2019. In total, 167 samples were collected and analysed, with 64 from 2018 and 104 from 2019. Once samples were received, organisms were identified visually to species level where possible, however, where this was not possible identification to genus level was acceptable. In the case of some sessile fauna samples, only identification to phylum level was possible. Over 30 distinct benthic species were recorded. Additional station information can be found in Table A2 in the Appendix A.

\subsection{Reagents and Chemicals}

Certified reference toxins were obtained from the Institute of Biotoxin Metrology, National Research Council Canada (NRCC, Halifax, NS, Canada). Toxins incorporated included GTX1-6, dcGTX2\&3, dcSTX, dcNEO, NEO, STX and C1\&2. Non-certified toxin standards were also received from CNC (Nelson, New Zealand) for C3\&4 and dcGTX1\&4. LC-MS grade water was produced by a MilliQ water purification system (Merck, Darmstadt, Germany). All solvents, reagents and chemicals were of LC-MS or HPLC grade, depending on the system specific requirements.

\subsection{Sample Preparation and Extraction}

Benthic organisms were assessed visually from each sampling point. When more than one organism of the same species was present in a specific location, individuals were all pooled and taken as a single representative sample. This was performed for all species except sunstars (C. papposus). In order to estimate whether toxicity of sunstars correlated with diameter, each sunstar was analysed separately. All samples were subsequently homogenised using Waring industrial blenders (Stamford, Connecticut, USA) and IKA Ultra Turrax homogenisers (Oxford, Oxfordshire, UK).

Samples collected in 2018 were extracted using two different methods, samples analysed utilising ultra-high-performance liquid chromatography with tandem mass spectrometry (LC-MS/MS) required a $5 \mathrm{~g}$ aliquot to be extracted using $5 \mathrm{~mL} \mathrm{1 \%} \mathrm{Acetic} \mathrm{acid,} \mathrm{using} \mathrm{a} \mathrm{single} \mathrm{step} \mathrm{dispersive} \mathrm{extraction} \mathrm{[116].}$ Where possible a 1:1 sample to solvent ratio was used. Samples analysed utilising pre-column oxidation liquid chromatography with fluorescence detection (LC-FLD) were extracted using a two-step exhaustive 
extraction [117], with $5 \mathrm{~g}$ aliquots extracted twice each using $3 \mathrm{~mL} \mathrm{1 \%} \mathrm{Acetic} \mathrm{acid.} \mathrm{For} \mathrm{small} \mathrm{samples} \mathrm{where}$ $5 \mathrm{~g}$ was not available, a scaled down extraction was used, with absolute amounts depending on the volume of homogenised tissue available. For samples where insufficient material was collected to perform both extractions, analysis by LC-MS/MS was prioritised due to wider range of quantified toxins incorporated. For samples collected during 2019, a unified extraction was performed to allow both methods to be applied to all samples. For these samples, a refined version of the LC-MS/MS extraction method was conducted, incorporating a higher solvent to sample ratio, specifically $2 \mathrm{~g}$ tissue plus $18 \mathrm{~mL} \mathrm{1 \%}$ Acetic acid.

Graphite solid phase extraction (SPE) clean-up was conducted to remove salts from the acidic extract [118], before dilution of SPE eluant with acetonitrile and LC-MS/MS analysis. For samples destined for LC-FLD, crude acidic extracts were subjected to C18 SPE clean up, followed by $\mathrm{pH}$ adjustment to $6 \pm 1$ and dilution to volume. Quantitation was achieved following the LC-FLD analysis of peroxide-oxidised C18 SPE-cleaned extracts and analysis of an un-oxidised extract to identify any naturally fluorescent co-extractives [117]. Due to the laborious nature of fully quantifying samples by LC-FLD and the expected high dcSTX and STX profile, a semi quantitative screen was initially performed to identify samples that contained any N-hydroxylated compounds, which if present were forwarded for ion exchange SPE and periodate oxidation of isolated fractions.

\subsection{Analysis of PSTs}

LC-MS/MS analysis was performed using an Agilent (Manchester, UK) 6495B triple quadrupole tandem mass spectrometer, with chromatography conducted using an Agilent 1290 Infinity II UHPLC system. Chromatographic separation was achieved using either an Agilent Poroshell 120 HILICZ (150 mm $\times 2.1 \mathrm{~mm} \times 2.7 \mu \mathrm{M})$ or a Waters Acquity BEH Amide $(150 \mathrm{~mm} \times 2.1 \mathrm{~mm} \times 1.7 \mu \mathrm{M})($ Elstree, Herefordshire, UK) column utilising a gradient solvent delivery. All instrument and chromatographic criteria are as described in [116]. An analysis of each toxin analogue was carried out using two multiple reaction monitoring (MRM) transitions, as detailed in [116], with quantitation performed using a six point calibration curve for each primary transition prepared using certified calibrants diluted in PST negative SPE-cleaned and diluted mussel extract. The LC-MS/MS method was validated previously for the quantification of GTX1-6, dcGTX1-4, C1-4, doSTX, dcSTX, dcNEO, NEO, STX in molluscs as well as the bacterially-derived neurotoxin Tetrodotoxin (TTX). Chromatograms of certified standards and a positive sunstar are detailed in Figure 8. LC-FLD analysis was performed on an Agilent 1200 LC system consisting of a quaternary pump, FLD, vacuum de-gasser, autosampler and thermostatically controlled column oven. Chromatographic separation was achieved using an Phenomenex Kinetex C18 (150 $\mathrm{mm} \times 4.6 \mathrm{~mm} \times 5 \mu \mathrm{M})$ (Torrance, CA, USA) column, adopting a solvent gradient as detailed in [119]. Quantitation of oxidized PSTs was achieved using a six-point calibration curve, which was prepared using certified calibrants diluted in 0.01M HAC. The LC-FLD method quantified the epimeric pairs, GTX1 and 4, GTX2 and 3, C1 and 2, C3 and 4 and dcGTX2 and 3, as well as the analogues GTX5, GTX6, NEO, dcNEO, dcSTX and STX. Chromatograms of certified standards and a positive sunstar are detailed in Figure 9.

\subsection{Data Analysis}

Toxin profiles were analysed using a K-means clustering algorithm [61], which assigns statistical centers based upon toxin content (based on each toxin as a percentage of total toxicity, expressed in $\mu \mathrm{g}$ STX eq. $/ \mathrm{kg}$ ) of samples and then 'sorts' samples into clusters based upon the statistical distance from each center. This approach was previously used for toxin profile analysis in [43]. A 95\% confidence paired students t-test was used to analyse statistical differences of samples $>80 \mu \mathrm{g}$ STX eq./kg between the LC-FLD and LC-MS methods. An analysis of means and standard deviations and creation of box plots of PST concentrations only used samples which detected PSTs above LOD, all samples <LOD were 
removed from the analysis. Prior to the statistical analysis, the toxicity variable was log transformed. An ranalysis of variance (ANOVA) was performed to investigate the most influencing variables on the toxicity. Normality of the residuals was checked. A Principal Component Analysis was then conducted to explore data variation among observations described by a mixture of qualitative and quantitative variables. The interaction between the most influential variables was analysed by comparing nested models including interaction terms or additive terms only [119]. Eventually, linear mixed effect models fitted to the data and followed by a Tukey's multiple comparison were used to estimate differences in toxicity between groups, and locations, respectively. All statistical analyses were performed using R statistical software [120], and packages PCAmixdata [121], nlme [122] and multcomp [123].

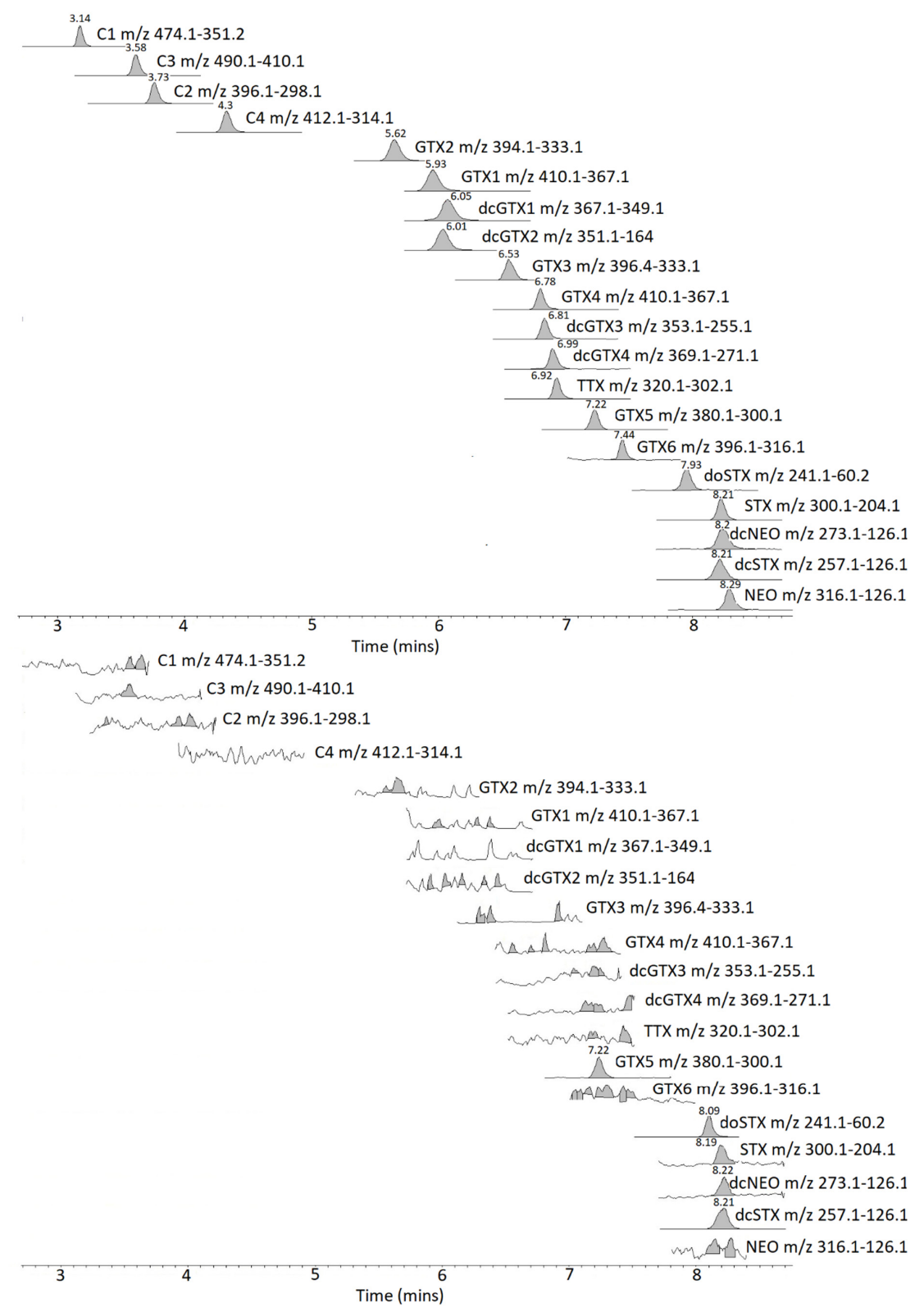

Figure 8. Chromatogram detailing LC-MS/MS quantitative $\mathrm{m} / \mathrm{z}$ transitions for certified standards (top) and a positive Sunstar (CEND181) (bottom). 


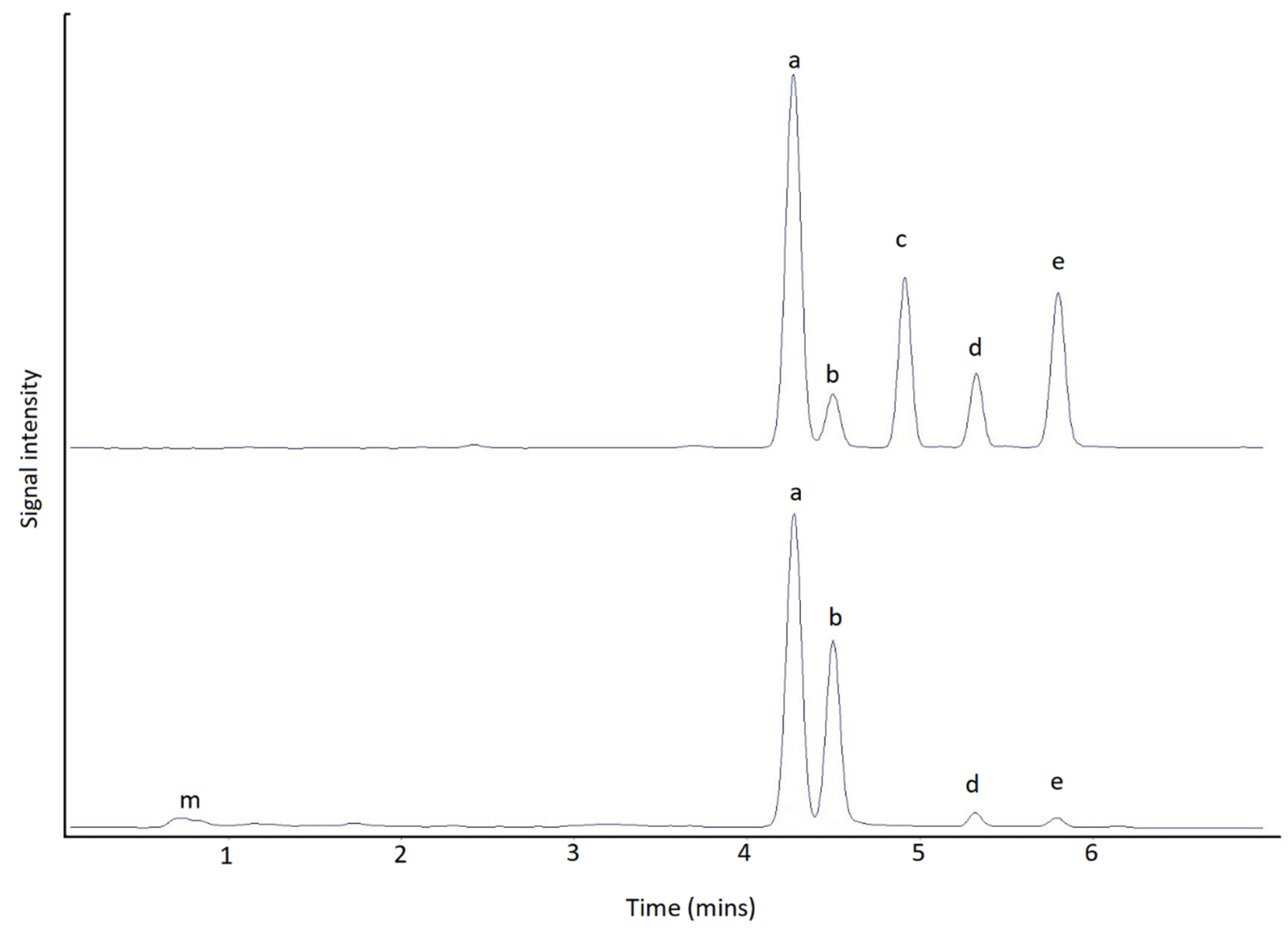

Figure 9. Chromatogram of LC-FLD for certified standards (top) and positive Sunstar (CEND181) (bottom). Key a-dcSTX quantitative, b-dcSTX qualitative, c-GTX2\&3, d-GTX 5, e-STX, m-matrix.

Author Contributions: Conceptualization, K.J.D., E.C., J.R.E. and A.D.T.; Data curation, K.J.D., R.G.H. and M.T.A.; Formal analysis, K.J.D., R.G.H., V.L., R.P.A., B.H.M., M.T.A., B.H., L.N.C. and J.R.E.; Funding acquisition, A.D.T.; Investigation, K.J.D. and A.D.T.; Methodology, K.J.D.; Project administration, A.D.T.; Resources, A.D.T.; Software, K.J.D., M.T.A. and L.N.C.; Supervision, A.D.T.; Writing-original draft, K.J.D.; Writing-review \& editing, K.J.D., R.G.H., R.P.A., A.M.L., B.H.M., M.T.A., J.R.E. and A.D.T. All authors have read and agreed to the published version of the manuscript.

Funding: This research was funded primarily by the EMFF Funding Project ENG3313, Cefas contract code C7847, with additional support from Interreg Alertox-Net EAPA-317-2016 (Atlantic Area Program).

Acknowledgments: The authors would like to thank the help and support of Elise Quinn, Eastern IFCA, throughout this project.

Conflicts of Interest: The authors declare no conflict of interest. 


\section{Appendix A}

Table A1. Full table of all samples analysed from both years, with total toxicities in $\mu \mathrm{g}$ STX eq./kg, species and taxanomic groups. nd; not detected, nt; not tested.

\begin{tabular}{|c|c|c|c|c|c|c|c|}
\hline Cefas ID & Year & Station & Common Name & Species & Group & $\begin{array}{l}\text { Total PST Detected by } \\
\text { LC-FLD ( } \mu \mathrm{g} \text { STX eq./kg) }\end{array}$ & $\begin{array}{c}\text { Total PST Detected by } \\
\text { LC-MS/MS ( } \mu \mathrm{g} \text { STX eq./kg) }\end{array}$ \\
\hline CEND 001 & 2018 & 22 & Rigid cushion starfish & Hippasteria phrygiana & Starfish \& Brittlestars (excl Sunstar) & 9 & 4 \\
\hline CEND 002 & 2018 & 22 & Whelk & Buccinidae (indet.) & Molluscs & 27 & 70 \\
\hline CEND 003 & 2018 & 22 & Woody canoe bubble & Scaphander lignarius & Molluscs & nt & 102 \\
\hline CEND 004 & 2018 & 22 & Sandstar & Astropecten irregularis & Starfish \& Brittlestars (excl Sunstar) & 13 & 66 \\
\hline CEND 005 & 2018 & 22 & Hermit crab & Pagurus bernhardus & $\begin{array}{c}\text { Crustacean (Anomura \& } \\
\text { Brachyura) }\end{array}$ & nt & nt \\
\hline CEND 006 & 2018 & 22 & Common starfish & Asterias rubens & Starfish \& Brittlestars (excl Sunstar) & 34 & 65 \\
\hline CEND 007 & 2018 & 22 & Circular crab & Atelecyclus rotundatus & $\begin{array}{c}\text { Crustacean (Anomura \& } \\
\text { Brachyura) }\end{array}$ & 4 & 54 \\
\hline CEND 008 & 2018 & 22 & Sea mouse & Aphrodita aculeata & Polychaeta & 25 & 359 \\
\hline CEND 009 & 2018 & 13 & Anemone & Actiniaria (indet.) & Actiniaria & nt & 5 \\
\hline CEND 010 & 2018 & 13 & Dead-man's fingers & Alcyonium digitatum & Sessile colonial fauna & 2 & 2 \\
\hline CEND 011 & 2018 & 13 & Common starfish & Asterias rubens & Starfish \& Brittlestars (excl Sunstar) & 16 & 28 \\
\hline CEND 012 & 2018 & 13 & Hermit crab & Pagurus bernhardus & $\begin{array}{c}\text { Crustacean (Anomura \& } \\
\text { Brachyura) }\end{array}$ & nt & 48 \\
\hline CEND 013 & 2018 & 13 & Whelk & $\begin{array}{l}\text { Neptunea antiqua } \\
\quad \text { (eggmass) }\end{array}$ & Molluscs & nt & 5 \\
\hline CEND 014 & 2018 & 8 & Masked crab & Corystes cassivelaunus & $\begin{array}{c}\text { Crustacean (Anomura \& } \\
\text { Brachyura) }\end{array}$ & 75 & 8 \\
\hline CEND 015 & 2018 & 8 & Square crab & Goneplax rhomboides & $\begin{array}{c}\text { Crustacean (Anomura \& } \\
\text { Brachyura) }\end{array}$ & 14 & 8 \\
\hline CEND 016 & 2018 & 8 & Swimming crabs & Liocarcinus sp. & $\begin{array}{c}\text { Crustacean (Anomura \& } \\
\text { Brachyura) }\end{array}$ & 4 & 13 \\
\hline CEND 017 & 2018 & 8 & Common starfish & Asterias rubens & Starfish \& Brittlestars (excl Sunstar) & 6 & 2 \\
\hline CEND 018 & 2018 & 8 & Dead-man's fingers & Alcyonium digitatum & Sessile colonial fauna & $\mathrm{nt}$ & 2 \\
\hline CEND 019 & 2018 & 77 & Circular crab & Atelecyclus rotundatus & $\begin{array}{c}\text { Crustacean (Anomura \& } \\
\text { Brachyura) }\end{array}$ & 15 & 13 \\
\hline CEND 020 & 2018 & 77 & Queen scallop & Aequipecten opercularis & Molluscs & 41 & 103 \\
\hline CEND 021 & 2018 & 77 & Swimming crabs & Liocarcinus sp. & $\begin{array}{c}\text { Crustacean (Anomura \& } \\
\text { Brachyura) }\end{array}$ & 8 & 14 \\
\hline CEND 022 & 2018 & 77 & Brittlestar & Ophiura ophiura & Starfish \& Brittlestars (excl Sunstar) & 32 & 39 \\
\hline CEND 023 & 2018 & 77 & Common starfish & Asterias rubens & Starfish \& Brittlestars (excl Sunstar) & 18 & 27 \\
\hline CEND 024 & 2018 & 77 & Rigid cushion starfish & Hippasteria phrygiana & Starfish \& Brittlestars (excl Sunstar) & 21 & 23 \\
\hline CEND 025 & 2018 & 77 & Seven-armed starfish & Luidia ciliaris & Starfish \& Brittlestars (excl Sunstar) & nt & 45 \\
\hline CEND 026 & 2018 & 77 & Squat lobster & Munida rugosa & $\begin{array}{c}\text { Crustacean (Anomura \& } \\
\text { Brachyura) }\end{array}$ & 14 & 57 \\
\hline CEND 027 & 2018 & 77 & Anemone & Actiniaria (indet.) & Actiniaria & nt & 150 \\
\hline CEND 028 & 2018 & 77 & Sea mouse & Aphrodita aculeata & Polychaeta & nt & 98 \\
\hline
\end{tabular}


Table A1. Cont.

\begin{tabular}{|c|c|c|c|c|c|c|c|}
\hline Cefas ID & Year & Station & Common Name & Species & Group & $\begin{array}{c}\text { Total PST Detected by } \\
\text { LC-FLD ( } \mu \mathrm{g} \text { STX eq./kg) }\end{array}$ & $\begin{array}{c}\text { Total PST Detected by } \\
\text { LC-MS/MS ( } \mu \mathrm{g} \text { STX eq./kg) }\end{array}$ \\
\hline CEND 029 & 2018 & 77 & Hermit crab & Pagurus bernhardus & $\begin{array}{c}\text { Crustacean (Anomura \& } \\
\text { Brachyura) }\end{array}$ & 27 & 63 \\
\hline CEND 030 & 2018 & 77 & Sandstar & Astropecten irregularis & Starfish \& Brittlestars (excl Sunstar) & 4 & 4 \\
\hline CEND 031 & 2018 & 3 & Brittlestar & Ophiura ophiura & Starfish \& Brittlestars (excl Sunstar) & nt & nd \\
\hline CEND 032 & 2018 & 3 & Shrimp & Crangon sp. & $\begin{array}{l}\text { Crustacean (Natania \& } \\
\text { Stomatopoda) }\end{array}$ & nt & nd \\
\hline CEND 033 & 2018 & 3 & Swimming crabs & Liocarcinus sp. & $\begin{array}{c}\text { Crustacean (Anomura \& } \\
\text { Brachyura) }\end{array}$ & nt & 14 \\
\hline CEND 034 & 2018 & 3 & Anemone & Actiniaria (indet.) & Actiniaria & 5 & 12 \\
\hline CEND 035 & 2018 & 3 & Common starfish & Asterias rubens & Starfish \& Brittlestars (excl Sunstar) & nt & 1 \\
\hline CEND 036 & 2018 & 3 & Netted dog whelk & Hinia reticulata & Molluscs & nt & nd \\
\hline CEND 037 & 2018 & 3 & Common shore crab & Carcinus maenas & $\begin{array}{c}\text { Crustacean (Anomura \& } \\
\text { Brachyura) }\end{array}$ & 15 & 44 \\
\hline CEND 038 & 2018 & 4 & Hermit crab & Paguris bernhardus & $\begin{array}{c}\text { Crustacean (Anomura \& } \\
\text { Brachyura) }\end{array}$ & 3 & 25 \\
\hline CEND 039 & 2018 & 4 & Brittlestar & Ophiura ophiura & Starfish \& Brittlestars (excl Sunstar) & nt & nd \\
\hline CEND 040 & 2018 & 4 & Common starfish & Asterias rubens & Starfish \& Brittlestars (excl Sunstar) & 3 & nd \\
\hline CEND 041 & 2018 & 4 & Velvet swimming crab & Necora puber & $\begin{array}{c}\text { Crustacean (Anomura \& } \\
\text { Brachyura) }\end{array}$ & 13 & 7 \\
\hline CEND 042 & 2018 & 4 & Sea urchin & Echinus sp. & Sea urchin & 13 & nd \\
\hline CEND 043 & 2018 & 4 & Sea urchin & Echinus sp. & Sea urchin & 27 & nd \\
\hline CEND 044 & 2018 & 4 & Swimming crabs & Liocarcinus sp. & $\begin{array}{c}\text { Crustacean (Anomura \& } \\
\text { Brachyura) }\end{array}$ & 47 & 16 \\
\hline CEND 045 & 2018 & 4 & Circular crab & Atelecyclus rotundatus & $\begin{array}{c}\text { Crustacean (Anomura \& } \\
\text { Brachyura) }\end{array}$ & 188 & 15 \\
\hline CEND 046 & 2018 & 1 & Shrimp & $\begin{array}{c}\text { Crangon sp. E Pandalus } \\
\text { sp. }\end{array}$ & $\begin{array}{l}\text { Crustacean (Natania \& } \\
\text { Stomatopoda) }\end{array}$ & 181 & 446 \\
\hline CEND 047 & 2018 & 1 & Dead-man's fingers & Alcyonium digitatum & Sessile colonial fauna & 88 & 36 \\
\hline CEND 048 & 2018 & 1 & Brittlestar & Ophiura ophiura & Starfish \& Brittlestars (excl Sunstar) & nt & 113 \\
\hline CEND 049 & 2018 & 1 & Hermit crab & Pagurus bernhardus & $\begin{array}{c}\text { Crustacean (Anomura \& } \\
\text { Brachyura) }\end{array}$ & $\mathrm{nt}$ & 52 \\
\hline CEND 050 & 2018 & 1 & Whelk & Buccinum undatum & Molluscs & nt & 48 \\
\hline CEND 051 & 2018 & 1 & Circular crab & Atelecyclus rotundatus & $\begin{array}{c}\text { Crustacean (Anomura \& } \\
\text { Brachyura) }\end{array}$ & nt & 7 \\
\hline CEND 052 & 2018 & 1 & Slipper limpet & Crepidula fornicata & Molluscs & nt & 172 \\
\hline CEND 053 & 2018 & 1 & Green sea urchin & Psammechinus miliaris & Sea urchin & nt & 23 \\
\hline CEND 054 & 2018 & 1 & Sea mouse & Aphrodita aculeata & Polychaeta & $\mathrm{nt}$ & 18 \\
\hline CEND 055 & 2018 & 1 & Common starfish & Asterias rubens & Starfish \& Brittlestars (excl Sunstar) & nt & 395 \\
\hline CEND 056 & 2018 & 7 & Common sea urchin & Echinus esculentus & Sea urchin & nt & 2 \\
\hline CEND 057 & 2018 & 7 & Bloody Henry starfish & Henricia sp. & Starfish \& Brittlestars (excl Sunstar) & nt & 15 \\
\hline CEND 058 & 2018 & 7 & Common starfish & Asterias rubens & Starfish \& Brittlestars (excl Sunstar) & 33 & 11 \\
\hline
\end{tabular}


Table A1. Cont.

\begin{tabular}{|c|c|c|c|c|c|c|c|}
\hline Cefas ID & Year & Station & Common Name & Species & Group & $\begin{array}{c}\text { Total PST Detected by } \\
\text { LC-FLD ( } \mu \mathrm{g} \text { STX eq./kg) }\end{array}$ & $\begin{array}{c}\text { Total PST Detected by } \\
\text { LC-MS/MS ( } \mu \text { g STX eq./kg) }\end{array}$ \\
\hline CEND 059 & 2018 & 7 & Seven-armed starfish & Luidia ciliaris & Starfish \& Brittlestars (excl Sunstar) & 26 & 72 \\
\hline CEND 060 & 2018 & 7 & Swimming crabs & $\begin{array}{l}\text { Liocarcinus holsatus } \mathcal{E} \\
\text { Liocarcinus depurator }\end{array}$ & $\begin{array}{c}\text { Crustacean (Anomura \& } \\
\text { Brachyura) }\end{array}$ & 73 & 11 \\
\hline CEND 061 & 2018 & 7 & Dead-man's fingers & Alcyonium digitatum & Sessile colonial fauna & nt & 12 \\
\hline CEND 062 & 2018 & 7 & Sunstar & Crossaster papposus & Sunstar & 302 & 227 \\
\hline CEND 063 & 2018 & 7 & Anemone & Actiniaria (indet.) & Actiniaria & $\mathrm{nt}$ & 22 \\
\hline CEND 064 & 2018 & 7 & Sea mouse & Aphrodita aculeata & Polychaeta & 14 & nd \\
\hline CEND 065 & 2019 & 71 & Common Starfish & Asterias rubens & Starfish \& Brittlestars (excl Sunstar) & 20 & 20 \\
\hline CEND 066 & 2019 & 71 & Sea urchin & Echinus sp. & Sea urchin & 10 & nd \\
\hline CEND 067 & 2019 & 71 & Sea cucumber & Parastichopus tremulus & Other & 9 & nd \\
\hline CEND 068 & 2019 & 71 & Red Cushion Starfish & Porania pulvillus & Starfish \& Brittlestars (excl Sunstar) & nd & nd \\
\hline CEND 076 & 2019 & 71 & Sunstar & Crossaster papposus & Sunstar & 120 & 135 \\
\hline CEND 077 & 2019 & 71 & Sunstar & Crossaster papposus & Sunstar & 132 & 131 \\
\hline CEND 078 & 2019 & 71 & Sunstar & Crossaster papposus & Sunstar & 176 & 169 \\
\hline CEND 079 & 2019 & 71 & Sunstar & Crossaster papposus & Sunstar & 103 & 98 \\
\hline CEND 080 & 2019 & 71 & Sponge & Porifera sp. & Sessile colonial fauna & 7 & nd \\
\hline CEND 081 & 2019 & 71 & Sea chervil & Alcyonidium diaphanum & Sessile colonial fauna & nd & 9 \\
\hline CEND 082 & 2019 & 71 & Anemone & Actiniaria (indet.) & Actiniaria & 9 & nd \\
\hline CEND 083 & 2019 & 71 & Woody canoe bubble & Scaphander lignarius & Molluscs & nd & nd \\
\hline CEND 084 & 2019 & 71 & Seven-armed Starfish & Luidia ciliaris & Starfish \& Brittlestars (excl Sunstar) & nd & nd \\
\hline CEND 085 & 2019 & 71 & Rosy Starfish & Stichastrella rosea & Starfish \& Brittlestars (excl Sunstar) & nd & 133 \\
\hline CEND 086 & 2019 & 71 & Goosefoot starfish & Anseropoda Placenta & Starfish \& Brittlestars (excl Sunstar) & 8 & 51 \\
\hline CEND 087 & 2019 & 71 & Portunid crabs & Portunidae (indet.) & $\begin{array}{c}\text { Crustacean (Anomura \& } \\
\text { Brachyura) }\end{array}$ & 24 & nd \\
\hline CEND 088 & 2019 & 71 & Brittlestar & Ophiura ophiura & Starfish \& Brittlestars (excl Sunstar) & 8 & nd \\
\hline CEND 089 & 2019 & 71 & Shrimp & Natantia sp. & $\begin{array}{l}\text { Crustacean (Natania \& } \\
\text { Stomatopoda) }\end{array}$ & 12 & nd \\
\hline CEND 090 & 2019 & 71 & Hermit Crab & Pagurus sp. & $\begin{array}{c}\text { Crustacean (Anomura \& } \\
\text { Brachyura) }\end{array}$ & 93 & 17 \\
\hline CEND 091 & 2019 & 71 & Rigid cushion starfish & Hippasteria phrygiana & Starfish \& Brittlestars (excl Sunstar) & 11 & nd \\
\hline CEND 092 & 2019 & 43 & Common Starfish & Asterias rubens & Starfish \& Brittlestars (excl Sunstar) & 12 & nd \\
\hline CEND 093 & 2019 & 43 & Sandstar & Astropecten irregularis & Starfish \& Brittlestars (excl Sunstar) & 14 & nd \\
\hline CEND 094 & 2019 & 43 & Rigid cushion starfish & Hippasteria phrygiana & Starfish \& Brittlestars (excl Sunstar) & nd & nd \\
\hline CEND 095 & 2019 & 43 & Hermit Crab & Pagurus bernhardus & $\begin{array}{c}\text { Crustacean (Anomura \& } \\
\text { Brachyura) }\end{array}$ & 11 & 8 \\
\hline CEND 096 & 2019 & 43 & Flying crab & Liocarcinus holsatus & $\begin{array}{c}\text { Crustacean (Anomura \& } \\
\text { Brachyura) }\end{array}$ & nd & nd \\
\hline CEND 097 & 2019 & 43 & Anemone & Actiniaria (indet.) & Actiniaria & nd & nd \\
\hline CEND 098 & 2019 & 43 & Sea urchin & Echinus sp. & Sea urchin & 26 & nd \\
\hline CEND 099 & 2019 & 43 & Whelk & Buccinidae (indet.) & Molluscs & nd & nd \\
\hline CEND 100 & 2019 & 43 & Dead-man's fingers & Alyconium digitatum & Sessile colonial fauna & 23 & nd \\
\hline
\end{tabular}


Table A1. Cont.

\begin{tabular}{|c|c|c|c|c|c|c|c|}
\hline Cefas ID & Year & Station & Common Name & Species & Group & $\begin{array}{l}\text { Total PST Detected by } \\
\text { LC-FLD ( } \mu \mathrm{g} \text { STX eq./kg) }\end{array}$ & $\begin{array}{c}\text { Total PST Detected by } \\
\text { LC-MS/MS ( } \mu \mathrm{g} \text { STX eq./kg) }\end{array}$ \\
\hline CEND 101 & 2019 & 43 & Sea urchin & Echinus acutus & Sea urchin & 9 & nd \\
\hline CEND 102 & 2019 & 43 & Slender colus & Colus gracilus & Molluscs & 18 & 48 \\
\hline CEND 103 & 2019 & 43 & Whelk & Buccinidae (indet.) & Molluscs & 20 & 15 \\
\hline CEND 104 & 2019 & 43 & Whelk & Buccinidae (indet.) & Molluscs & nd & 38 \\
\hline CEND 105 & 2019 & 43 & Sea mouse & Aphrodita aculeata & Polychaeta & 30 & $\mathrm{Nd}$ \\
\hline CEND 106 & 2019 & 13 & Rigid cushion starfish & Hippasteria phrygiana & Starfish \& Brittlestars (excl Sunstar) & nd & $\mathrm{Nd}$ \\
\hline CEND 107 & 2019 & 13 & Hermit Crab & Pagurus sp. & $\begin{array}{c}\text { Crustacean (Anomura \& } \\
\text { Brachyura) }\end{array}$ & nd & $\mathrm{Nd}$ \\
\hline CEND 108 & 2019 & 13 & Sea mouse & Aphrodita aculeata & Polychaeta & 587 & 357 \\
\hline CEND 109 & 2019 & 13 & Dead-man's fingers & Alyconium digitatum & Sessile colonial fauna & nd & nd \\
\hline CEND 110 & 2019 & 13 & Brittlestar & Ophiura ophiura & Starfish \& Brittlestars (excl Sunstar) & 8 & nd \\
\hline CEND 111 & 2019 & 13 & Anemone & Actiniaria (indet.) & Actiniaria & 31 & 11 \\
\hline CEND 112 & 2019 & 13 & Common Starfish & Asterias rubens & Starfish \& Brittlestars (excl Sunstar) & 34 & 10 \\
\hline CEND 113 & 2019 & 13 & Plumose anemone & Metridium senile & Actiniaria & 9 & 27 \\
\hline CEND 114 & 2019 & 13 & Bivalve & Bivalvia (indet.) & Molluscs & 28 & 17 \\
\hline CEND 115 & 2019 & 1 & Dead-man's fingers & Alcyonium digitatum & Sessile colonial fauna & nd & nd \\
\hline CEND 116 & 2019 & 1 & Brittlestar & Ophiura ophiura & Starfish \& Brittlestars (excl Sunstar) & 8 & nd \\
\hline CEND 117 & 2019 & 1 & Sea mouse & Aphrodita aculeata & Polychaeta & nd & nd \\
\hline CEND 118 & 2019 & 1 & Hermit crab & Pagurus bernhardus & $\begin{array}{c}\text { Crustacean (Anomura \& } \\
\text { Brachyura) }\end{array}$ & nd & nd \\
\hline CEND 119 & 2019 & 1 & Common Starfish & Asterias rubens & Starfish \& Brittlestars (excl Sunstar) & 14 & nd \\
\hline CEND 120 & 2019 & 1 & Green sea urchin & Psammechinus miliaris & Sea urchin & nd & nd \\
\hline CEND 121 & 2019 & 1 & Echiuran worm & Echiura sp. & Other & nd & nd \\
\hline CEND 122 & 2019 & 1 & Inachidae crab & Inachus sp. & $\begin{array}{c}\text { Crustacean (Anomura \& } \\
\text { Brachyura) }\end{array}$ & 66 & 13 \\
\hline CEND 123 & 2019 & 1 & Anemone & Actiniaria (indet.) & Actiniaria & 92 & 13 \\
\hline CEND 124 & 2019 & 1 & Whelk & Buccinum undatum & Molluscs & 1 & nd \\
\hline CEND 125 & 2019 & 1 & Shrimp & $\begin{array}{c}\text { Crangon sp. \& Rissoides } \\
\text { desmarseti }\end{array}$ & $\begin{array}{l}\text { Crustacean (Natania \& } \\
\text { Stomatopoda) }\end{array}$ & nd & 17 \\
\hline CEND 126 & 2019 & 1 & Crabs & $\begin{array}{c}\text { Portunidae sp. E Ebalia } \\
\text { sp. }\end{array}$ & $\begin{array}{c}\text { Crustacean (Anomura \& } \\
\text { Brachyura) }\end{array}$ & 25 & nd \\
\hline CEND 127 & 2019 & 3 & Hermit Crab & Pagurus bernhardus & $\begin{array}{c}\text { Crustacean (Anomura \& } \\
\text { Brachyura) }\end{array}$ & nd & 12 \\
\hline CEND 128 & 2019 & 3 & Swimming crabs & $\begin{array}{l}\text { Liocarcinus holsatus } \mathcal{E} \\
\text { Liocarcinus depurator }\end{array}$ & $\begin{array}{c}\text { Crustacean (Anomura \& } \\
\text { Brachyura) }\end{array}$ & nd & 9 \\
\hline CEND 129 & 2019 & 3 & Common shore crab & Carcinus maenas & $\begin{array}{c}\text { Crustacean (Anomura \& } \\
\text { Brachyura) }\end{array}$ & nd & nd \\
\hline CEND 130 & 2019 & 3 & Sea mouse & Aphrodita aculeata & Polychaeta & 44 & nd \\
\hline CEND 131 & 2019 & 3 & Sea chervil & Alcyonidium diaphanum & Sessile colonial fauna & 1486 & 2091 \\
\hline CEND 132 & 2019 & 3 & Common Starfish & Asterias rubens & Starfish \& Brittlestars (excl Sunstar) & 21 & nd \\
\hline CEND 133 & 2019 & 3 & Brittlestar & Ophiura ophiura & Starfish \& Brittlestars (excl Sunstar) & 14 & 29 \\
\hline
\end{tabular}


Table A1. Cont.

\begin{tabular}{|c|c|c|c|c|c|c|c|}
\hline Cefas ID & Year & Station & Common Name & Species & Group & $\begin{array}{c}\text { Total PST Detected by } \\
\text { LC-FLD ( } \mu \mathrm{g} \text { STX eq./kg) }\end{array}$ & $\begin{array}{c}\text { Total PST Detected by } \\
\text { LC-MS/MS ( } \mu \mathrm{g} \text { STX eq./kg) }\end{array}$ \\
\hline CEND 134 & 2019 & 3 & Shrimp & Crangon sp. & $\begin{array}{l}\text { Crustacean (Natania \& } \\
\text { Stomatopoda) }\end{array}$ & 16 & 18 \\
\hline CEND 135 & 2019 & 3 & Spider crab & Macropodia sp. & $\begin{array}{c}\text { Crustacean (Anomura \& } \\
\text { Brachyura) }\end{array}$ & 35 & 31 \\
\hline CEND 136 & 2019 & 3 & Green sea urchin & Psammechinus miliaris & Sea urchin & 10 & 19 \\
\hline CEND 137 & 2019 & 2 & Common Starfish & Asterias rubens & Starfish \& Brittlestars (excl Sunstar) & 317 & 354 \\
\hline CEND 138 & 2019 & 2 & Green sea urchin & Psammechinus miliaris & Sea urchin & 377 & 257 \\
\hline CEND 139 & 2019 & 2 & Sea chervil & Alcyonidium diaphanum & Sessile colonial fauna & 2744 & 1461 \\
\hline CEND 140 & 2019 & 2 & Brittlestar & Ophiura ophiura & Starfish \& Brittlestars (excl Sunstar) & 593 & 489 \\
\hline CEND 141 & 2019 & 2 & Sea mouse & Aphrodita aculeata & Polychaeta & 443 & 386 \\
\hline CEND 142 & 2019 & 2 & Swimming crabs & Liocarcinus sp. & $\begin{array}{c}\text { Crustacean (Anomura \& } \\
\text { Brachyura) }\end{array}$ & 76 & 88 \\
\hline CEND 143 & 2019 & 2 & Whelk & Baccinum undatum & Molluscs & 133 & 110 \\
\hline CEND 144 & 2019 & 2 & Sea chervil & Alcyonidium diaphanum & Sessile colonial fauna & 562 & 288 \\
\hline CEND 145 & 2019 & ? & Rigid cushion starfish & Hippasteria phrygiana & Starfish \& Brittlestars (excl Sunstar) & nd & nd \\
\hline CEND 146 & 2019 & 7 & Sea mouse & Aphrodita aculeata & Polychaeta & nd & nd \\
\hline CEND 147 & 2019 & 7 & Common Starfish & Asterias rubens & Starfish \& Brittlestars (excl Sunstar) & nd & 10 \\
\hline CEND 148 & 2019 & 7 & Bloody Henry starfish & Henricia oculata & Starfish \& Brittlestars (excl Sunstar) & nd & 11 \\
\hline CEND 149 & 2019 & 7 & Sunstar & Crossaster papposus & Sunstar & 654 & 1275 \\
\hline CEND 156 & 2019 & 7 & Swimming crabs & $\begin{array}{l}\text { Liocarcinus holsatus } \mathcal{E} \\
\text { Liocarcinus depurator }\end{array}$ & $\begin{array}{c}\text { Crustacean (Anomura \& } \\
\text { Brachyura) }\end{array}$ & nd & nd \\
\hline CEND 157 & 2019 & 7 & Masked crab & Corystes cassivelaunus & $\begin{array}{c}\text { Crustacean (Anomura \& } \\
\text { Brachyura) }\end{array}$ & nd & nd \\
\hline CEND 158 & 2019 & 7 & Dead-man's fingers & Alcyonium digitatum & Sessile colonial fauna & nd & nd \\
\hline CEND 159 & 2019 & 7 & Mermaids glove & Haliclona oculata & Sessile colonial fauna & 21 & nd \\
\hline CEND 160 & 2019 & 4 & Common starfish & Asterias rubens & Starfish \& Brittlestars (excl Sunstar) & nd & nd \\
\hline CEND 161 & 2019 & 4 & Sea mouse & Aphrodita aculeata & Polychaeta & nd & nd \\
\hline CEND 162 & 2019 & 4 & Green sea urchin & Psammechinus miliaris & Sea urchin & nd & nd \\
\hline CEND 163 & 2019 & 4 & Hermit Crab & Pagurus bernhardus & $\begin{array}{c}\text { Crustacean (Anomura \& } \\
\text { Brachyura) }\end{array}$ & nd & nd \\
\hline CEND 164 & 2019 & 4 & Brittlestar & Ophiura ophiura & Starfish \& Brittlestars (excl Sunstar) & nd & nd \\
\hline CEND 165 & 2019 & 4 & Swimming crabs & $\begin{array}{l}\text { Liocarcinus holsatus } \mathcal{E} \\
\text { Liocarcinus depurator }\end{array}$ & $\begin{array}{c}\text { Crustacean (Anomura \& } \\
\text { Brachyura) }\end{array}$ & nd & 15 \\
\hline CEND 166 & 2019 & 4 & Circular Crab & Atelecyclus sp. & $\begin{array}{c}\text { Crustacean (Anomura \& } \\
\text { Brachyura) }\end{array}$ & nd & nd \\
\hline CEND 167 & 2019 & 4 & Whelk & Buccinum undatum & Molluscs & nd & nd \\
\hline CEND 168 & 2019 & 22 & Rigid cushion starfish & Hippasteria phrygiana & Starfish \& Brittlestars (excl Sunstar) & nd & nd \\
\hline CEND 169 & 2019 & 22 & Anemone & Actiniaria (indet.) & Actiniaria & 14 & 45 \\
\hline CEND 170 & 2019 & 22 & Sea mouse & Aphrodita aculeata & Polychaeta & 37 & 46 \\
\hline CEND 171 & 2019 & 22 & Sandstar & Astropecten irregularis & Starfish \& Brittlestars (excl Sunstar) & nd & 183 \\
\hline CEND 172 & 2019 & 22 & Woody canoe bubble & Scaphander lignarius & Molluscs & nd & nd \\
\hline
\end{tabular}


Table A1. Cont.

\begin{tabular}{|c|c|c|c|c|c|c|c|}
\hline Cefas ID & Year & Station & Common Name & Species & Group & $\begin{array}{l}\text { Total PST Detected by } \\
\text { LC-FLD ( } \mu \mathrm{g} \text { STX eq./kg) }\end{array}$ & $\begin{array}{c}\text { Total PST Detected by } \\
\text { LC-MS/MS ( } \mu \text { g STX eq./kg) }\end{array}$ \\
\hline CEND 173 & 2019 & 22 & Seven-armed Starfish & Luidia ciliaris & Starfish \& Brittlestars (excl Sunstar) & nd & nd \\
\hline CEND 174 & 2019 & 22 & Brittlestar & Ophiura ophiura & Starfish \& Brittlestars (excl Sunstar) & nd & 27 \\
\hline CEND 175 & 2019 & 22 & Shrimp & Natantia (indet.) & $\begin{array}{l}\text { Crustacean (Natania \& } \\
\text { Stomatopoda) }\end{array}$ & 7 & nd \\
\hline CEND 176 & 2019 & 77 & Sea mouse & Aphrodita aculeata & Polychaeta & 12 & 13 \\
\hline CEND 177 & 2019 & 77 & Rigid cushion starfish & Hippasteria phrygiana & Starfish \& Brittlestars (excl Sunstar) & nd & nd \\
\hline CEND 178 & 2019 & 77 & Brittlestar & Ophiura ophiura & Starfish \& Brittlestars (excl Sunstar) & nd & nd \\
\hline CEND 179 & 2019 & 77 & Sandstar & Astropecten irregularis & Starfish \& Brittlestars (excl Sunstar) & nd & 6 \\
\hline CEND 180 & 2019 & 77 & Anemone & Actiniaria (indet.) & Actiniaria & 22 & 72 \\
\hline CEND 181 & 2019 & 73 & Sunstar & Crossaster papposus & Sunstar & 1600 & 1102 \\
\hline
\end{tabular}

Table A2. Table describing additional station information.

\begin{tabular}{|c|c|c|c|c|c|c|c|}
\hline Station & Coordinates & Bottom Salinity & Surface Salinity & Bottom Temp. $\left({ }^{\circ} \mathrm{C}\right)$ & Surface Temp. $\left({ }^{\circ} \mathrm{C}\right)$ & Depth (m) & Date \\
\hline 1 & 51:42N 01:45E & 33.7 & 34.5 & 19.6 & 19.8 & 33 & 11 August 2018 \\
\hline 3 & 51:50N 03:37E & 32.4 & 32.5 & 20.9 & 21 & 24 & 11 August 2018 \\
\hline 4 & $52: 49 \mathrm{~N} 02: 45 \mathrm{E}$ & 34.4 & 34.4 & 17.6 & 17.6 & 38 & 12 August 2018 \\
\hline 7 & 53:59N 00:15E & 34.5 & 34.5 & 12.6 & 12.4 & 53 & 14 August 2018 \\
\hline 13 & 54:56N 00:16W & 34.7 & 34.5 & 7.4 & 16.3 & 77 & 14 August 2018 \\
\hline 77 & 55:56N 01:27W & 34.8 & 34.8 & 9.5 & 13.9 & 84 & 7 September 2018 \\
\hline 22 & $55: 35 \mathrm{~N}$ 00:49W & 34.9 & 34.9 & 7.4 & 15.3 & 96 & 7 September 2018 \\
\hline 8 & 53:56N 01:17E & 34.8 & 34.8 & 14.2 & 16.4 & 42 & 14 August 2018 \\
\hline 1 & 51:45N 01:44E & 35.1 & 35.0 & 18.8 & 19 & 30 & 7 August 2019 \\
\hline 2 & 51:35N 02:46E & 34.8 & 34.8 & 19.6 & 19.6 & 32 & 7 August 2019 \\
\hline 3 & 51:50N 03:38E & 33.5 & 33.4 & 20.1 & 20.2 & 27 & 8 August 2019 \\
\hline 4 & $52: 50 \mathrm{~N} 02: 46 \mathrm{E}$ & 34.7 & 34.7 & 17.8 & 18.1 & 41 & 8 August 2019 \\
\hline 7 & 53:60N 00:16E & 34.4 & 34.4 & 13.1 & 14.5 & 55 & 11 August 2019 \\
\hline 13 & $54: 33 \mathrm{~N} 00: 02 \mathrm{~W}$ & 34.6 & 34.6 & 9.6 & 15.9 & 65 & 11 August 2019 \\
\hline 22 & 55:35N 00:48W & 34.9 & 34.5 & 8.4 & 16.2 & 99 & 18 August 2019 \\
\hline 71 & 61:01N 00:60W & 35.4 & 35.3 & 9.6 & 13.3 & 132 & 24 August 2019 \\
\hline 43 & 57:19N 02:27E & 35.1 & 34.8 & 7.7 & 16.9 & 84 & 28 August 2019 \\
\hline 73 & $61: 16 \mathrm{~N} 00: 34 \mathrm{E}$ & 35.4 & 35.4 & 9.3 & 13.4 & 170 & 24 August 2019 \\
\hline 50 & 57:43N 05:10E & 35.3 & 34.0 & 8 & 16 & 110 & 27 August 2019 \\
\hline 77 & 55:58N 01:25W & 34.7 & 34.5 & 9.3 & 15 & 90 & 18 August 2019 \\
\hline
\end{tabular}




\section{References}

1. Botana, L.M. Seafood and freshwater toxins: Pharmacology, physiology and detection, chapter 2: Diversity of marine and freshwateralgal toxins. In Seafood and Freshwater Toxins: Pharmacology, Physiology and Detection; Marcel Dekker Inc.: New York, NY, USA, 2000; pp. 20-24.

2. Deeds, J.R.; Landsberg, J.H.; Etheridge, S.M.; Pitcher, G.C.; Longan, S.W. Non-traditional vectors for paralytic shellfish poisoning. Mar. Drugs 2008, 6, 308-348. [CrossRef]

3. Cadoret, J.-P.; Garnier, M.; Saint-Jean, B. Microalgae, functional genomics and biotechnology. Adv. Bot. Res. 2012, 64, 285-341. [CrossRef]

4. Pearson, L.A.; Mihali, T.; Moffitt, M.C.; Kellmann, R.; Neilan, B.A. On the chemistry, toxicology and genetics of the cyanobacterial toxins, microcystin, nodularin, saxitoxin and cylindrospermopsin. Mar. Drugs 2010, 8 , 1650-1680. [CrossRef]

5. Wiese, M.; D’Agostino, P.M.; Mihali, T.; Moffitt, M.C.; Neilan, B.A. Neurotoxic alkaloids: Saxitoxin and its analogs. Mar. Drugs 2010, 8, 2185-2211. [CrossRef]

6. Thottumkara, A.P.; Parsons, W.H.; DuBois, J. Saxitoxin. Angew. Chemie Int. Ed. 2014, 53, 5760-5784. [CrossRef] [PubMed]

7. Etheridge, S.M. Paralytic shellfish poisoning: Seafood safety and human health perspectives. Toxicon 2010, 56, 108-122. [CrossRef] [PubMed]

8. Anon. Regulation (EC) No 854/2004 of the european parliament and of the council of 29 April 2004 laying down specific rules for the organisation of official controls on products of animal origin intended for human consumption. Off. J. Eur. Union 2004, 139, 206-320.

9. Anon. Regulation (EC) No 853/2004 of the european parliament and of the council of 29 April 2004 laying down specific hygiene rules for food of animal origin. Off. J. Eur. 2004, 7, 69-74.

10. Alexander, J.; Benford, D.; Cockburn, A.; Cravedi, J.-P.; Dogliotti, E.; Domenico, D.D.; Fernández-Cruz, M.L.; Fink-Gremmels, J.; Fürst, P.; Galli, C.; et al. Scientific opinion of the panel on contaminants in the food chain on a request from the European Commission on marine biotoxins in shellfish-Saxitoxin group. EFSA J. 2009, 1019, $1-76$.

11. Quiblier, C.; Susanna, W.; Isidora, E.-S.; Mark, H.; Aurélie, V.; Jean-François, H. A review of current knowledge on toxic benthic freshwater cyanobacteria-Ecology, toxin production and risk management. Water Res. 2013, 47, 5464-5479. [CrossRef]

12. Aráoz, R.; Molgó, J.; De Marsac, N.T. Neurotoxic cyanobacterial toxins. Toxicon 2010, 56, 813-828. [CrossRef] [PubMed]

13. Smith, F.M.J.; Wood, S.A.; Van Ginkel, R.; Broady, P.A.; Gaw, S. First report of saxitoxin production by a species of the freshwater benthic cyanobacterium, Scytonema Agardh. Toxicon 2011, 57, 566-573. [CrossRef] [PubMed]

14. Borges, H.; Branco, L.H.; Martins, M.; Lima, C.; Barbosa, P.; Lira, G.; Bittencourt-Oliveira, M.D.C.; Molica, R. Cyanotoxin production and phylogeny of benthic cyanobacterial strains isolated from the northeast of Brazil. Harmful Algae 2015, 43, 46-57. [CrossRef]

15. Ahern, K.S.; Ahern, C.R.; Savige, G.M.; Udy, J.W. Mapping the distribution, biomass and tissue nutrient levels of a marine benthic cyanobacteria bloom (Lyngbya majuscula). Mar. Freshw. Res. 2007, 58, 883. [CrossRef]

16. Scholz, B.; Liebezeit, G. Screening for competition effects and allelochemicals in benthic marine diatoms and cyanobacteria isolated from an intertidal flat (southern North Sea). Phycology 2012, 51, 432-450. [CrossRef]

17. Stal, L.J.; van Gemerden, H.; Krumbein, W.E. Structure and development of a benthic marine microbial mat. FEMS Microbiol. Lett. 1985, 31, 111-125. [CrossRef]

18. Paerl, H.W.; Paul, V.J. Climate change: Links to global expansion of harmful cyanobacteria. Water Res. 2012, 46, 1349-1363.

19. Brown, L. Distribution, diversity and toxin composition of the genus alexandrium (Dinophyceae) in Scottish waters distribution, diversity and toxin composition of the genus alexandrium (Dinophyceae) in Scottish waters. Eur. J. Phycol. 2010, 45, 375-393. [CrossRef] 
20. Lewis, A.M.; Coates, L.N.; Turner, A.D.; Percy, L.; Lewis, J. A review of the global distribution of Alexandrium minutum (Dinophyceae) and comments on ecology and associated paralytic shellfish toxin profiles, with a focus on Northern Europe. J. Phycol. 2018, 54, 581-598. [CrossRef]

21. Anderson, D.M.; Alpermann, T.J.; Cembella, A.D.; Collos, Y.; Masseret, E.; Montresor, M. The globally distributed genus alexandrium: Multifaceted roles in marine ecosystems and impacts on human health. Harmful Algae 2012, 14, 10-35. [CrossRef]

22. Nascimento, S.M.; Purdie, D.A.; Lilly, E.L.; Larsen, J.; Morris, S. Toxin profile, pigment composition, and large subunit rDNA phylogenetic analysis of an Alexandrium minutum (Dinophyceae) strain isolated from the fleet lagoon, United Kingdom. J. Phycol. 2005, 41, 343-353. [CrossRef]

23. Martin, J.L.; LeGresley, M.M.; Hanke, A.R. Thirty years-Alexandrium fundyense cyst, bloom dynamics and shellfish toxicity in the Bay of Fundy, eastern Canada. Deep. Res. Part II Top. Stud. Oceanogr. 2014, 103, 27-39. [CrossRef]

24. Anderson, D.M.; Stock, C.A.; Keafer, B.A.; Nelson, A.B.; Thompson, B.; McGillicuddy, J.D.; Keller, M.; Matrai, P.A.; Martin, J. Alexandrium fundyense cyst dynamics in the gulf of maine. Deep. Sea Res. Part II: Top. Stud. Oceanogr. 2005, 52, 2522-2542. [CrossRef]

25. Natsuike, M.; Nagai, S.; Matsuno, K.; Saito, R.; Tsukazaki, C.; Yamaguchi, A.; Imai, I. Abundance and distribution of toxic alexandrium tamarense resting cysts in the sediments of the chukchi sea and the eastern bering sea. Harmful Algae 2013, 27, 52-59. [CrossRef]

26. Persson, A.; Smith, B.C.; Wikfors, G.H.; Quilliam, M. Grazing on toxic alexandrium fundyense resting cysts and vegetative cells by the eastern oyster (Crassostrea virginica). Harmful Algae 2006, 5, 678-684. [CrossRef]

27. Suarez-isla, B.A. Saxitoxin and other paralytic toxins: Toxicological profile. Mar. Freshw. Toxins 2015, 1-16. [CrossRef]

28. Landsberg, J.H. The effects of harmful algal blooms on aquatic organisms. Rev. Fish. Sci. 2002, 10, 113-390. [CrossRef]

29. White, A.W. Sensitivity of marine fishes to toxins from the red-tide dinoflagellate Gonyaulax excavata and implications for fish kills. Mar. Boil. 1981, 65, 255-260. [CrossRef]

30. Costa, P.R. Impact and effects of paralytic shellfish poisoning toxins derived from harmful algal blooms to marine fish. Fish Fish. 2014, 17, 226-248. [CrossRef]

31. Montoya, N.; Akselman, R.; Franco, J.; Carreto, J.I. Paralytic shellfish toxins and mackerel (Scomber japonicus) mortality in the argentine sea. Harmful Toxic Algal. Bloom. 1996, 1, 417-420.

32. Jensen, S.; Lacazeb, J.P.; Hermannb, G.; Kershawa, J.; Brownlowc, A.; Turnerd, A.; Halla, A. Toxicon Detection and effects of harmful algal toxins in Scottish harbour seals and potential links to population decline. Toxicon 2015, 97, 1-14. [CrossRef] [PubMed]

33. Hernández, M.; Robinson, I.; Aguilar, A.; González, L.M.; López-Jurado, L.F.; Reyero, M.I.; Cacho, E.; Franco, J.; López-Rodas, V.; Costas, E. Did algal toxins cause monk seal mortality? Nature 1998, 393, 28-29. [CrossRef]

34. Kvitek, R.G.; DeGunge, A.R.; Beitler, M.K. Paralytic shellfish poisoning toxins mediate feeding behavior of sea otters. Limnol. Oceanogr. 1991, 36, 393-404. [CrossRef]

35. Fraser, S.M. Mortality of shags and other sea birds caused by paralytic shellfish poison. Nature 1968, 220, $23-24$.

36. Mann, R.; Allen, S.M.; Boersma, P.D. Marine birds and harmful algal blooms: Sporadic victims or under-reported events? Harmful Algae 2003, 2, 1-17.

37. Bif, M.B.; Yunes, J.S.; Resgalla, C. Evaluation of mysids and sea urchins exposed to saxitoxins. Environ. Toxicol. Pharmacol. 2013, 36, 819-825.

38. Ferrer, R.P.; Lunsford, E.T.; Candido, C.M.; Strawn, M.L.; Pierce, K.M. Saxitoxin and the ochre sea star: Molecule of keystone significance and a classic keystone species. Integr. Comp. Boil. 2015, 55, 533-542. [CrossRef]

39. Andrade-Villagrán, P.V.; Navarro, J.M.; Aliste, S.; Chaparro, O.R.; Ortíz, A. Trophic transfer of paralytic shellfish toxin (PST): Physiological and reproductive effects in the carnivorous gastropod Acanthina monodon (Pallas, 1774). Aquat. Toxicol. 2019, 212, 37-46. [CrossRef]

40. Li, S.-C.; Wang, W.-X.; Hsieh, D.P. Effects of toxic dinoflagellate alexandrium tamarense on the energy budgets and growth of two marine bivalves. Mar. Environ. Res. 2002, 53, 145-160. [CrossRef] 
41. Navarro, J.; González, K.; Cisternas, B.; López, J.A.; Chaparro, O.R.; Segura, C.J.; Córdova, M.; Suárez-Isla, B.; Fernández-Reiriz, M.J.; Labarta, U. Contrasting physiological responses of two populations of the razor clam tagelus dombeii with different histories of exposure to paralytic shellfish poisoning (PSP). PLOS ONE 2014, 9, e105794. [CrossRef]

42. Turner, A.D.; Dhanji-Rapkova, M.; Dean, K.; Milligan, S.; Hamilton, M.; Thomas, J.; Poole, C.; Haycock, J.; Spelman-Marriott, J.; Watson, A.; et al. Fatal canine intoxications linked to the presence of saxitoxins in stranded marine organisms following winter storm activity. Toxins 2018, 10, 94. [CrossRef] [PubMed]

43. Turner, A.D.; Stubbs, B.; Coates, L.; Dhanji-Rapkova, M.; Hatfield, R.G.; Lewis, A.M.; Rowland-Pilgrim, S.; O'Neil, A.; Stubbs, P.; Ross, S.; et al. Variability of paralytic shellfish toxin occurrence and profiles in bivalve molluscs from Great Britain from official control monitoring as determined by pre-column oxidation liquid chromatography and implications for applying immunochemical tests. Harmful Algae 2014, 31, 87-99. [CrossRef] [PubMed]

44. Turner, A.D.; Lewis, A.M.; O'Neil, A.; Hatfield, R.G. Transformation of paralytic shellfish poisoning toxins in UK surf clams (Spisula solida) for targeted production of reference materials. Toxicon 2013, 65, 41-58. [CrossRef] [PubMed]

45. Artigas, M.L.; Vale, P.; Gomes, S.S.; Botelho, M.J.; Rodrigues, S.M.; Amorim, A.; Henriques, M.J.B. Profiles of paralytic shellfish poisoning toxins in shellfish from portugal explained by carbamoylase activity. J. Chromatogr. 2007, 1160, 99-105. [CrossRef]

46. Lin, H.-P.; Cho, Y.; Yashiro, H.; Yamada, T.; Oshima, Y. Purification and characterization of paralytic shellfish toxin transforming enzyme from Mactra chinensis. Toxicon 2004, 44, 657-668. [CrossRef] [PubMed]

47. Cho, Y.; Ogawa, N.; Takahashi, M.; Lin, H.-P.; Oshima, Y. Purification and characterization of paralytic shellfish toxin-transforming enzyme, sulfocarbamoylase I, from the Japanese bivalve peronidia venulosa. Biochim. Biophys. Acta (BBA)-Proteins Proteom. 2008, 1784, 1277-1285. [CrossRef]

48. Smith, A.E.; Grant, F.; Ferguson, C.M.J.; Gallacher, S. Biotransformations of paralytic shellfish toxins by bacteria isolated from bivalve molluscs. Appl. Environ. Microbiol. 2001, 67, 2345-2353. [CrossRef]

49. Shumway, S.E. Phycotoxin related shellfish poisoning: Bivalve molluscs are not the only vectors. Rev. Fish. Sci. 1995, 3, 1-31. [CrossRef]

50. Jester, R.; Rhodes, L.; Beuzenberg, V. Uptake of paralytic shellfish poisoning and spirolide toxins by paddle crabs (Ovalipes catharus) via a bivalve vector. Harmful Algae 2009, 8, 369-376. [CrossRef]

51. Kwong, R.W.; Wang, W.-X.; Lam, P.K.; Yu, P.K.N.; Lam, P.K. The uptake, distribution and elimination of paralytic shellfish toxins in mussels and fish exposed to toxic dinoflagellates. Aquat. Toxicol. 2006, 80, 82-91. [CrossRef]

52. Turner, A.D.; Tarnovius, S.; Goya, A.B. Paralytic shellfish toxins in the marine gastropods zidona dufresnei and adelomelon beckii from argentina: Toxicity and toxin profiles. J. Shellfish. Res. 2014, 33, 519-530. [CrossRef]

53. Terrazas, J.O.; Contreras, H.R.; García, C. Prevalence, variability and bioconcentration of saxitoxin-group in different marine species present in the food chain. Toxins 2017, 9, 190. [CrossRef] [PubMed]

54. Silva, M.; Felpeto, A.B.; Rodriguez, P.; Otero, P.; Azevedo, J.; Alfonso, A.; Botana, L.M.; Vasconcelos, V. New invertebrate vectors for PST, spirolides and okadaic acid in the north atlantic. Mar. Drugs 2013, 11, 1936-1960. [CrossRef] [PubMed]

55. Asakawa, M.; Nishimura, F.; Miyazawa, K.; Noguchi, T. Occurance of paralytic shellfish poison in the starfish Asteria amurensis in Kure Bay, Hiroshima prefecture, Japan. Toxins 1997, 35, 1081-1087.

56. Ito, K.; Asakawa, M.; Sida, Y.; Miyazawa, K. Occurrence of paralytic shellfish poison (PSP) in the starfish Asterina pectinifera collected from the Kure Bay, Hiroshima Prefecture, Japan. Toxicon 2003, 41, 291-295. [CrossRef]

57. Lin, S.-J.; Tsai, Y.-H.; Lin, H.; Hwang, D. Paralytic toxins in Taiwanese starfish Astrpecten scoparius. Toxicon 1998, 36, 799-803. [CrossRef]

58. Silva, M.; Rey, V.; Barreiro, A.; Kaufmann, M.; Neto, A.I.; Hassouani, M.; Sabour, B.; Botana, A.; Botana, L.M.; Vasconcelos, V. Paralytic shellfish toxins occurrence in non-traditional invertebrate vectors from north atlantic waters (Azores, Madeira, and Morocco). Toxins 2018, 10, 362. [CrossRef]

59. Cusson, M.; Bourget, E. Global patterns of macroinvertebrate production in marine benthic habitats. Mar. Ecol. Prog. Ser. 2005, 297, 1-14. [CrossRef] 
60. Bremner, J.; Rogers, S.; Frid, C. Assessing functional diversity in marine benthic ecosystems: A comparison of approaches. Mar. Ecol. Prog. Ser. 2003, 254, 11-25. [CrossRef]

61. Aravind, H.; Rajgopal, C.; Soman, K.P. A simple approach to clustering in excel. Int. J. Comput. Appl. 2010, 11, 19-25.

62. EFSA. Marine biotoxins in shellfish-Saxitoxin group. EFSA J. 2009, 7, 1019.

63. Jen, H.-C.; Nguyen, T.A.-T.; Wu, Y.-J.; Hoang, T.; Arakawa, O.; Lin, W.-F.; Hwang, D.-F. Tetrodotoxin and paralytic shellfish poisons in gastropod species from Vietnam analyzed by high-performance liquid chromatography and liquid chromatography-tandem mass spectrometry. J. Food Drug Anal. 2014, 22, 178-188. [CrossRef]

64. Alderman, D.J. Monitoring and surveillance of biological contaminants and disease in the aquatic environment. Minist. Agric. For. Fish. 1993, 19, 1-35.

65. Oikawa, H.; Fujita, T.; Satomi, M.; Suzuki, T.; Kotani, Y.; Yano, Y. Accumulation of paralytic shellfish poisoning toxins in the edible shore crab telmessus acutidens. Toxicon 2002, 40, 1593-1599. [CrossRef]

66. Jester, R.J.; Baugh, K.A.; Lefebvre, K.A. Presence of Alexandrium catenella and paralytic shellfish toxins in finfish, shellfish and rock crabs in Monterey Bay, California, USA. Mar. Boil. 2009, 156, 493-504. [CrossRef]

67. McLeod, C.; Kiermeier, A.; Stewart, I.; Tan, J.; Turnbull, A.; Madigan, T. Paralytic shellfish toxins in Australian southern rock lobster (Jasus edwardsii): Acute human exposure from consumption of hepatopancreas. Hum. Ecol. Risk Assessment: Int. J. 2018, 24, 1872-1886. [CrossRef]

68. Costa, P.R.; Costa, S.T.; Braga, A.; Rodrigues, S.M.; Vale, P. Relevance and challenges in monitoring marine biotoxins in non-bivalve vectors. Food Control. 2017, 76, 24-33. [CrossRef]

69. DeGrasse, S.; Vanegas, C.; Conrad, S. Paralytic shellfish toxins in the sea scallop placopecten magellanicus on georges bank: Implications for an offshore roe-on and whole scallop fishery. Deep. Sea Res. Part II: Top. Stud. Oceanogr. 2014, 103, 301-307. [CrossRef]

70. Horner, R.; Greengrove, C.; Davies-Vollum, K.; Gawel, J.; Postel, J.; Cox, A. Spatial distribution of benthic cysts of Alexandrium catenella in surface sediments of Puget Sound, Washington, USA. Harmful Algae 2011, 11, 96-105. [CrossRef]

71. Oshima, Y.; Bolch, C.J.; Hallegraeff, G.M. Toxin composition of resting cysts of Alexandrium tamerense (Dinophycae). Toxicon 1992, 30, 1539-1544. [CrossRef]

72. Anderson, D.M.; Taylor, C.D.; Armbrust, E.V. The effects of darkness and anaerobiosis dinoflagellate cyst germination. Limnol. Ocean. 1987, 32, 340-351. [CrossRef]

73. Ayres, P.; Cullum, M. Paralytic shellfish poisoning: An account of investigations into mussel toxicity in England. Fis.Res.Tec. MAFF 1978, 40, 1-23.

74. Joint, I.; Lewis, J.; Aiken, J.; Proctor, R.; Moore, G.; Higman, W.; Donald, M. Interannual variability of PSP outbreaks on the north east UK coast. J. Plankton Res. 1997, 19, 937-956. [CrossRef]

75. Lewis, J.; Higman, W.; Kuenstner, S. Occurrence of alexandrium sp. Cysts in sediments from the north east coast of britain. In Harmful Marine Algal Blooms; Lassus, P., Arzul, G., Erard-Le Denn, E., Gentien, P., Macrcaillou-Le Baut, C., Eds.; Lavoisier: Paris, France, 1995; pp. 175-180.

76. Cefas. Harmful Algal Blooms (HABS) Surveillance Programmes and Monitoring. Available online: https: //www.cefas.co.uk/data-and-publications/habs/ (accessed on 13 July 2020).

77. Gallacher, S.; Smith, E.A. Bacteria and paralytic shellfish toxins. Protist 1999, 150, 245-255. [CrossRef]

78. Bane, V.; Lehane, M.; Dikshit, M.; O’Riordan, A.; Furey, A. Tetrodotoxin: Chemistry, Toxicity, source, distribution and detection. Toxins 2014, 6, 693-755. [CrossRef] [PubMed]

79. Narita, H. Vibrio alginolyticus, a TTX-producing bacterium isolated from the starfish astropecten polyacanthus. Nippon. Suisan Gakkaishi 1987, 53, 617-621. [CrossRef]

80. Turner, A.D.; Hatfield, R.G.; Rapkova, M.; Higman, W.; Algoet, M.; Suarez-Isla, B.A.; Córdova, M.; Caceres, C.; Riet, J.; Gibbs, R.S.; et al. Comparison of AOAC 2005.06 LC official method with other methodologies for the quantitation of paralytic shellfish poisoning toxins in UK shellfish species. Anal. Bioanal. Chem. 2010, 399, 1257-1270. [CrossRef] 
81. Ben-Gigirey, B.; Rodríguez-Velasco, M.; Otero, A.; Vieites, J.; Cabado, A.G. A comparative study for PSP toxins quantification by using MBA and HPLC official methods in shellfish. Toxicon 2012, 60, 864-873. [CrossRef]

82. Dean, K.J.; Hatfield, R.G.; Turner, A.D. Performance characteristics of a refined AOAC 2005.06 pre-column oxidation liquid chromatography with fluorescence detection and hydrophilic interaction liquid chromatography with tandem mass spectrometry methods for the determination of paralytic shellfi. J. AOAC Int. 2020, 98, 628-635.

83. Medina-Elizalde, J.; García-Mendoza, E.; Turner, A.D.; Sánchez-Bravo, Y.A.; Murillo-Martínez, R. Transformation and depuration of paralytic shellfish toxins in the geoduck clam panopea globosa from the northern gulf of california. Front. Mar. Sci. 2018, 5, 1-13. [CrossRef]

84. Taleb, H.; Vale, P.; Jaime, E.; Blaghen, M. Study of paralytic shellfish poisoning toxin profile in shellfish from the Mediterranean shore of Morocco. Toxicon 2001, 39, 1855-1861. [CrossRef]

85. Botelho, M.J.; Vale, C.; Grilo, R.V.; Ferreira, J.; Henriques, M.J.B. Uptake and release of paralytic shellfish toxins by the clam Ruditapes decussatus exposed to Gymnodinium catenatum and subsequent depuration. Mar. Environ. Res. 2012, 77, 23-29. [CrossRef] [PubMed]

86. Kotaki, Y.; Oshima, Y.; Yasumoto, T. Bacterial transformation of paralytic shellfish toxins in coral reef crabs and a marine snail. Nippon. Suisan Gakkaishi 1985, 51, 1009-1013. [CrossRef]

87. Smith, E.; Mackintosh, F.; Grant, F.; Gallacher, S. Sodium channel blocking (SCB) activity and transformation of paralytic shellfish toxins (PST) by dinoflagellate-associated bacteria. Aquat. Microb. Ecol. 2002, 29, 1-9. [CrossRef]

88. Bricelj, V.; Lee, J.; Cembella, A.; Anderson, D. Uptake kinetics of paralytic shellfish toxins from the dinoflagellate Alexandrium fundyense in the mussel Mytilus edulis. Mar. Ecol. Prog. Ser. 1990, 63, 177-188. [CrossRef]

89. Bricelj, V.M.; Shumway, S.E. Paralytic shellfish toxins in bivalve molluscs: Occurrence, transfer kinetics, and biotransformation. Rev. Fish. Sci. 1998, 6, 315-383. [CrossRef]

90. Sakamoto, S.; Sato, S.; Ogata, T.; Kodama, M. Formation of intermediate conjugates in the reductive transformation of gonyautoxins to saxitoxins by thiol compounds. Fish. Sci. 2000, 66, 136-141. [CrossRef]

91. Jaime, E.; Gerdts, G.; Luckas, B. In vitro transformation of PSP toxins by different shellfish tissues. Harmful Algae 2007, 6, 308-316. [CrossRef]

92. Sharp, J.H.; Winson, M.K.; Porter, J.S. Bryozoan metabolites: An ecological perspective. Nat. Prod. Rep. 2007, 24, 659-673. [CrossRef]

93. Carle, J.; Christophersen, C. Correction. dogger bank itch. the allergen is (2-Hydroxyethyl)dimethylsulfonium Ion. J. Am. Chem. Soc. 1981, 103, 2143. [CrossRef]

94. Porter, J.; Ellis, J.; Hayward, P.; Rogers, S.; Callaway, R. Geographic variation in the abundance and morphology of the bryozoan alcyonidium diaphanum (Ctenostomata: Alcyonidiidae) in UK coastal waters. J. Mar. Boil. Assoc. UK 2002, 82, 529-535. [CrossRef]

95. Carlson, H.R.; Pfister, C.A. A seventeen-year study of the rose star crossaster papposus population in a coastal bay in southeast Alaska. Mar. Boil. 1999, 133, 223-230. [CrossRef]

96. Harwood, T.; Selwood, A.I.; Van Ginkel, R.; Waugh, C.; McNabb, P.S.; Munday, R.; Hay, B.; Thomas, K.; Quilliam, M.A.; Malhi, N.; et al. Paralytic shellfish toxins, including deoxydecarbamoyl-STX, in wild-caught Tasmanian abalone (Haliotis rubra). Toxicon 2014, 90, 213-225. [CrossRef] [PubMed]

97. McLeod, C.; Dowsett, N.; Hallegraeff, G.; Harwood, D.T.; Hay, B.; Ibbott, S.; Malhi, N.; Murray, S.A.; Smith, K.; Tan, J.; et al. Accumulation and depuration of paralytic shellfish toxins by Australian abalone Haliotis rubra: Conclusive association with Gymnodinium catenatum dinoflagellate blooms. Food Control. 2017, 73, 971-980. [CrossRef]

98. Etheridge, S.M.; Pitcher, G.C.; Roesler, C.S. Depuration and transformation of PSP toxins in the South African abalone haliotis midae. Harmful Algae 2002, 10, 98-101.

99. Ellis, J.; Rogers, S. The distribution, relative abundance and diversity of echinoderms in the eastern English Channel, Bristol Channel, and Irish Sea. J. Mar. Boil. Assoc. U. K. 2000, 80, 127-138. [CrossRef]

100. Paramor, O.A. MEFEPO North Sea Atlas; University of Liverpool: Liverpool, UK, 2009. 
101. Anderson, D.M.; Keafer, B.A.; Kleindinst, J.L.; McGillicuddy, J.D.; Martin, J.L.; Norton, K.; Pilskaln, C.H.; Smith, J.L.; Sherwood, C.R.; Butman, B. Alexandrium fundyense cysts in the Gulf of Maine: Long-term time series of abundance and distribution, and linkages to past and future blooms. Deep. Sea Res. Part II: Top. Stud. Oceanogr. 2013, 103, 6-26. [CrossRef] [PubMed]

102. Anderson, D.M.; White, A.W.; Baden, D.G. The occurrence of PSP toxins in intertidal organisms. In Toxic Dinoflagellates; Elsevier: Amsterdam, The Netherlands, 1985; pp. 467-472.

103. Cefas, P.-H.M.; Masefield, R.; Bell, D.E. Edible Crab (Cancer Pagurus); Technical Report for Cefas Stock Status: Lowestoft, UK, 2014.

104. Lawton, P. Predatory interaction between the brachyuran crab Cancer pagurus and decapod crustacean prey. Mar. Ecol. Prog. Ser. 1989, 52, 169-179. [CrossRef]

105. Lawton, P.; Hughes, R. Foraging behaviour of the crab Cancer pagurus feeding on the gastropods Nucella lapillus and Littorina littorea: Comparisons with optimal foraging theory. Mar. Ecol. Prog. Ser. 1985, 27, $143-154$. [CrossRef]

106. Hall, S.; Basford, D.; Robertson; Raffaelli, D.; Tuck, I. Patterns of recolonisation and the importance of pit-digging by the crab Cancer pagurus in a subtidal sand habitat. Mar. Ecol. Prog. Ser. 1991, 72, 93-102. [CrossRef]

107. Mascaro, M.; Seed, R. Foraging behavior of juvenile Carcinus maenas (L.) and Cancer pagurus L. Mar. Boil. 2001, $139,1135-1145$.

108. Oikawa, H.; Fujita, T.; Saito, K.; Watabe, S.; Satomi, M.; Yano, Y. Comparison of paralytic shellfish poisoning toxin between carnivorous crabs (Telmessus acutidens and Charybdis japonica) and their prey mussel (Mytilus galloprovincialis) in an inshore food chain. Toxicon 2004, 43, 713-719. [CrossRef] [PubMed]

109. Jiang, T.; Niu, T.; Xu, Y.-X. Transfer and metabolism of paralytic shellfish poisoning from scallop (Chlamys nobilis) to spiny lobster (Panulirus stimpsoni). Toxicon 2006, 48, 988-994. [CrossRef] [PubMed]

110. Llewellyn, L.E. Haemolymph protein in xanthid crabs: Its selective binding of saxitoxin and possible role in toxin bioaccumulation. Mar. Boil. 1997, 128,599-606. [CrossRef]

111. Shumway, S.E.; Sherman, S.A.; Cembella, A.D.; Selvin, R. Accumulation of Paralytic Shellfish Toxins by Surfclams, Spisula solidissima (Dilwyn, 1897) in the Gulf of maine: Seasonal changes, Distribution between Tissues, and Notes on Feeding Habits. Nat. Toxins 1994, 2, 236-251. [CrossRef]

112. Graneli, E.; Sundstrom, B.; Edler, L.; Anderson, D.M. Uptake and distribution of PSP toxins in butter clams. In Toxic Marine Phytoplankton; Elsevier: Amsterdam, The Netherlands, 1990; pp. 257-262.

113. Ellis, J.R. Personal communication, 13 July 2020.

114. Bbc. Beach Safe for Dogs after Alert. Available online: http://news.bbc.co.uk/1/hi/england/northamptonshire/ 4662752.stm (accessed on 13 July 2006).

115. Turner, A.D.; Dhanji-Rapkova, M.; Fong, S.Y.; Hungerford, J.; McNabb, P.S.; Boundy, M.J.; Harwood, D.T. Ultrahigh-Performance hydrophilic interaction liquid chromatography with tandem mass spectrometry method for the determination of paralytic shellfish toxins and tetrodotoxin in mussels, oysters, clams, cockles, and scallops: Collaborative study. J. AOAC Int. 2019, 103, 1-30. [CrossRef]

116. Jinrong, X.; Zhongming, C. AOAC Official Method 2005.06 Paralytic shellfish poisoning toxins in shellfish prechromatographic oxidation and liquid chromatography with fluorescence detection. J. AOAC Int. 2005, 23, 366-369.

117. Turner, A.D.; McNabb, P.; Harwood, D.T.; Selwood, A.I.; Boundy, M.J. Single-Laboratory Validation of a Multitoxin ultra-Performance LC-Hydrophilic interaction LC-MS/MS method for quantitation of paralytic shellfish toxins in bivalve shellfish. J. AOAC Int. 2015, 98, 609-621. [CrossRef]

118. Hatfield, R.G.; Punn, R.; Algoet, M.; Turner, A.D. A rapid method for the analysis of paralytic shellfish toxins utilizing standard pressure HPLC: Refinement of AOAC 2005.06. J. AOAC Int. 2016, 99, 475-480. [CrossRef]

119. Chambers, T.M.; Hastie, T. Statistical Models in S.; Wadsworth \& Brooks: Cole, OH, USA, 1992.

120. Lloyd, D. An introduction to. Ind. Commer. Train. 1978, 10, 11-18. [CrossRef]

121. Chavent, M.; Kuentz-Simonet, V.; Labenne, A.; Saracco, J. Multivariate Analysis of Mixed Data: The R Package PCAmixdata; Cornel University: Ithaca, NY, USA, 2015. 
122. Pinheiro, J.; Bates, D.; DebRoy, S.; Sarkar, D.; R Core team. nlme: Linear and Nonlinear Mixed Effects Models; R Package Nlme Version; R Core team: Vienna, Austria, 2018; Volume 3, pp. 1-83.

123. Hothorn, T.; Bretz, F.; Westfall, P. Simultaneous Inference in General Parametric Models. Biom. J. 2008, 50, $346-363$. [CrossRef] [PubMed]

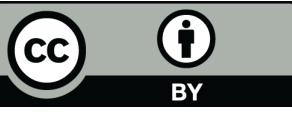

(C) 2020 by the authors. Licensee MDPI, Basel, Switzerland. This article is an open access article distributed under the terms and conditions of the Creative Commons Attribution (CC BY) license (http://creativecommons.org/licenses/by/4.0/). 